\title{
Royal AHOLD: A FaILURE OF CoRPoRATE GovernanCE
}

Abe de Jong, Douglas V. DeJong, Gerard Mertens en Peter Roosenboom

\begin{tabular}{|l|l|}
\hline \multicolumn{2}{|l|}{ ERIM REPORT SERIES RESEARCH IN MANAGEMENT } \\
\hline ERIM Report Series reference number & ERS-2005-002-F\&A \\
\hline Publication & January 2005 \\
\hline Number of pages & 51 \\
\hline Email address corresponding author & a.jong@fbk.eur.nl \\
\hline Address & Erasmus Research Institute of Management (ERIM) \\
& Rotterdam School of Management / Rotterdam School of \\
& Economics \\
& Erasmus Universiteit Rotterdam \\
& P.O. Box 1738 \\
& 3000 DR Rotterdam, The Netherlands \\
& Phone: $\quad+31104081182$ \\
& Fax: $\quad+31104089640$ \\
& Email: info@erim.eur.nl \\
& Internet: $\quad$ www.erim.eur.nl \\
\hline
\end{tabular}

Bibliographic data and classifications of all the ERIM reports are also available on the ERIM website: www.erim.eur.nl 


\section{ERASMUS RESEARCH INSTITUTE OF MANAGEMENT}

\section{REPORT SERIES}

\section{RESEARCH IN MANAGEMENT}

\begin{tabular}{|c|c|c|}
\hline \multicolumn{3}{|c|}{ BIBLIOGRAPHIC DATA AND CLASSIFICATIONS } \\
\hline Abstract & \multicolumn{2}{|c|}{$\begin{array}{l}\text { Royal Ahold (Koninklijke Ahold NV) was one of the major success stories in the 1990s } \\
\text { and is one of the major failures in corporate governance, suffering a complete meltdown } \\
\text { in 2003. This clinical study analyzes Ahold's growth strategy through acquisitions and } \\
\text { isolates the cause of the failed strategy, i.e. the absence of internal as well as external } \\
\text { oversight of management's strategy. This study details the consequences of the strategy: } \\
\text { bad acquisitions, an accounting scandal and the loss of investor confidence. It illustrates } \\
\text { how initially a family and later professional management exploited the intent of the law } \\
\text { and existing regulatory structures to maintain absolute control of the company. It } \\
\text { analyzes in detail the applicable governance mechanisms of Ahold that were designed to } \\
\text { hold the self-interest of the parties in check. It asks the reader to consider whether these } \\
\text { governance mechanisms, properly implemented, might have helped prevent Ahold or a } \\
\text { situation similar to Ahold. }\end{array}$} \\
\hline \multirow{3}{*}{$\begin{array}{l}\text { Library of Congress } \\
\text { Classification } \\
\text { (LCC) } \\
\text { LCC Webpage }\end{array}$} & \multicolumn{2}{|l|}{ Mission: HF 5001-6182 } \\
\hline & \multicolumn{2}{|l|}{ Programme: HF 4001-4280.7 } \\
\hline & Paper:HD 2741+ & Corporate Governance \\
\hline \multirow{3}{*}{$\begin{array}{l}\text { Journal of Economic } \\
\text { Literature } \\
\text { (JEL) } \\
\text { JEL Webpage } \\
\end{array}$} & \multicolumn{2}{|l|}{ Mission: $\mathrm{M}$} \\
\hline & \multicolumn{2}{|l|}{ Programme : G 3} \\
\hline & Paper: L10 & Firm Strategy \\
\hline \multicolumn{3}{|c|}{ Gemeenschappelijke Onderwerpsontsluiting (GOO) } \\
\hline \multirow[t]{3}{*}{ Classification GOO } & \multicolumn{2}{|l|}{ Mission: 85.00} \\
\hline & \multicolumn{2}{|l|}{ Programme: 85.30} \\
\hline & Paper: 85.10 & Strategisch beleid \\
\hline \multirow[t]{3}{*}{ Keywords GOO } & \multicolumn{2}{|l|}{ Mission: Bedrijfskunde / Bedrijfseconomie } \\
\hline & \multicolumn{2}{|c|}{ Programme: Financieel management, besliskunde } \\
\hline & \multicolumn{2}{|c|}{ Paper: Corporate governance, Ahold, Regulering } \\
\hline Free keywords & \multicolumn{2}{|c|}{$\begin{array}{l}\text { international economics, financial economics, law and economics, } \\
\text { corporate governance, regulation. }\end{array}$} \\
\hline
\end{tabular}




\title{
Royal Ahold: \\ A Failure of Corporate Governance
}

\author{
Abe de Jong* \\ Department of Financial Management \\ Erasmus University Rotterdam \\ a.jong@fbk.eur.nl \\ Douglas V. DeJong \\ Tippie College of Business \\ University of Iowa \\ douglas-dejong@uiowa.edu \\ Gerard Mertens \\ Department of Financial Management \\ Erasmus University Rotterdam \\ g.mertens@fbk.eur.nl \\ Peter Roosenboom \\ Department of Financial Management \\ Erasmus University Rotterdam \\ proosenboom@fbk.eur.nl
}

Current Draft: January 14, 2005

Keywords: international economics, financial economics, law and economics, corporate governance, regulation.

JEL Classification Numbers: F36, G38, K22

* Corresponding author. Erasmus University Rotterdam, Department of Financial Management, Room F4-32, P.O.Box 1738, 3000 DR Rotterdam, The Netherlands; phone +31-10-4081022. The authors would like to thank Marco Becht, Willem Buijink, Paul Frentrop, Reggy Hooghiemstra, Bruce Johnson, Bill Kinney, Miriam Koning, Willem Schramade, Roy Suddaby and Bart van Halder for helpful comments and Shan-Twan The for excellent research assistance. 


\title{
Royal Ahold: \\ A Failure of Corporate Governance
}

\begin{abstract}
Royal Ahold (Koninklijke Ahold NV) was one of the major success stories in the 1990s and is one of the major failures in corporate governance, suffering a complete meltdown in 2003. This clinical study analyzes Ahold's growth strategy through acquisitions and isolates the cause of the failed strategy, i.e. the absence of internal as well as external oversight of management's strategy. This study details the consequences of the strategy: bad acquisitions, an accounting scandal and the loss of investor confidence. It illustrates how initially a family and later professional management exploited the intent of the law and existing regulatory structures to maintain absolute control of the company. It analyzes in detail the applicable governance mechanisms of Ahold that were designed to hold the self-interest of the parties in check. It asks the reader to consider whether these governance mechanisms, properly implemented, might have helped prevent Ahold or a situation similar to Ahold.
\end{abstract}




\section{Introduction}

The rise and fall of Royal Ahold (Koninklijke Ahold NV) is an important event in corporate governance. Headquartered in The Netherlands, Ahold is one of the world's largest international retail grocery and food service companies. At its peak in 2001, Ahold's reported sales and profits were $€ 66.6$ billion and $€ 1.1$ billion and it operated 5,155 stores in 27 countries with nearly a quarter of a million employees. Ahold began as a family firm in 1887 and went public in 1948. Ahold was a family-controlled business under the Heijn family, operating primarily in the Netherlands for over 100 years. In 1989, Ahold under went a transition from a family-controlled to a managementcontrolled firm. Following this transition, Ahold experienced a remarkable period of success. It generated over a 1,000\% return for its shareholders and had a market capitalization of €30.6 billion by November 2001. In 2003, Ahold suffered a complete meltdown. The ensuing period found a firm in complete disarray: a failed strategy, an accounting scandal, the firing of professional management, and litigation filings from all parts of the world. Shareholders lost most of their returns generated since 1989.

We analyze Ahold's growth strategy through acquisitions and its consequences. Moeller, Schlingemann and Stulz's (forthcoming) general description of mergers and acquisitions and their consequences during the 1991 to 2001 period fits the profile of Ahold. Acquiring firms' shareholders in this period lost a substantial amount, substantially more after adjusting for the cost of the acquisitions than in the 1980s. These large losses were clustered in the 1998-2001 period; were incurred by a small number of firms when their firm value was high; in addition these firms were serial acquirers of companies and had been successful prior to 1998. Moeller, Schlingemann and Stulz speculate but do not explain why this happened. For Ahold, we isolate the cause of its failed strategy, the absence of internal as well as external oversight of management's strategy, and the consequences, bad acquisitions, an accounting scandal and the loss of investor confidence.

Moeller, Schlingemann and Stulz suggest their evidence is consistent with Jensen's view (2004) that high values put pressure on management to maintain growth levels as well as giving management more discretion to make poor acquisitions that value growth over shareholder value. They go on to state that their result is also consistent with the inability to sustain the firm's strategy of growth through acquisition or the strategy is not going to be as profitable as expected. We document for Ahold that poor corporate governance led to aggressive accounting by management which inflated stock prices that allowed management to undertake poor acquisitions. The company's investor relations, 
which made Ahold a 'best in class' company and its CEO the 'best manager,' was a success but a two-edged sword; it effectively maintained the company's stock price but also placed management under substantial pressure to maintain the growth implied by the stock price.

The fall of Ahold sent shock waves through the corporate governance landscape. The family used Dutch corporate law and a small blockholding to control Ahold with a dispersed ownership structure. The transition to professional management in 1989 left Ahold with dispersed shareholders but no major blockholder. When professional management raised capital from institutional investors, management denied them their voting rights by exploiting regulations that allow Dutch companies to issue non-voting certificates rather than voting shares. Thus, blockholders were not able to supplant the role of the family as a monitor of professional management. With a dispersed ownership structure and weak minority rights, management was unconstrained. The surprising aspect of the Ahold saga is that it is unclear why the family and professional management should have done anything differently or that we would have expected them to do anything differently. The exploitation of regulatory structures is not unique but rather a general characteristic with implications beyond Ahold. This clinical study provides insights on how family and management's objectives interact with (and within) the constraints of outside regulations and their consequences. Our evidence is particularly relevant to Europe where a common characteristic of firms is their majority and/or family control structure without blockholder monitoring or disciplining by the market for corporate control. The general concern is that these ownership structures often hinder the performance of publicly traded firms (Faccio and Lang, 2002).

For regulators, Ahold shattered the illusion that corporate governance was a U.S. problem; Ahold became "Europe’s Enron” (The Economist, March 1, 2003). It caused Dutch and European policymakers to rethink their approach to corporate governance. In The Netherlands, a committee on corporate governance was installed on March 10, 2003 (Tabaksblat Committee, 2003) to restore confidence in public companies. In the U.S., the Public Company Accounting Oversight Board (PCAOB) that regulates the accounting profession under the Sarbanes-Oxley Act used Ahold as an example to successfully negotiate the extension of its oversight to European accounting firms working in the U.S. or working on foreign companies listed in the U.S. (Wall Street Journal, March 5, 2003). First principles of corporate governance are generally understood in the academic literature and in the policy arena (Demsetz, 1983, Hart, 1995 and Agrawal and Knoeber, 1996). We use the Organization for Economic Co-operation and Development's Principles of Corporate Governance, the international standard by which corporate 
governance codes are often measured, to illustrate first principles. We then analyze in detail the applicable governance mechanisms of Ahold that were designed to hold the self-interest of the parties in check. We ask the reader to consider whether these mechanisms, properly implemented, might have helped prevent Ahold's collapse or a situation similar to Ahold.

The paper is organized as follows. Section 2 details Ahold's growth strategy and its implementation. Section 3 addresses the accounting scandal and the loss of investor confidence. Section 4 addresses the family and management's exploitation of existing corporate governance structures and regulations by analyzing Ahold's corporate governance mechanisms in detail. Section 5 concludes with potential lessons learned.

\section{Growth strategy and implementation ${ }^{1}$}

\subsection{Ahold's growth strategy}

Over three generations of the Heijn family, Ahold evolved from a single grocery store in 1887 to a food company with a dominant position in the Netherlands. In 1989, when family management was supplanted by professional management, Ahold was the largest food retailer. Ahold included the Albert Heijn supermarket chain and a franchise, Schuitema, supplying independent groceries. Specialty stores include Etos, a chain of drug stores, and Alberto, a chain of liquor and wine stores. Combining grocery and specialty chains, Ahold had a total market share of about $45 \%$ in the Netherlands. Ahold had a solid base of operations in the US that contributed significantly to Ahold's overall sales and profits, and a small number of other European activities. Ahold operated its foreign store chains under their own name, management and local identity.

Starting in 1989, Ahold's ambition under professional management was to be in the same league as Wal-Mart and Carrefour, the number one and two internationally ranked retail companies. Figure 1 presents a comparison of Ahold, Carrefour and WalMart's stock price performances. Ahold planned to accomplish this ambition by maintaining its dominant position in the Netherlands, developing a critical mass in the US in order to establish synergies at the widest possible level within Ahold USA, and considering other international opportunities (Deutsche Morgan Grenfell, December 12, 1997). Table 1 and 2 show Ahold's growth and international expansion. The information consists of sales and operating profits, in total and by geographic region, total assets and key ratios. 
Under CEO Pierre Everaert, the first professional manager appointed CEO in 1989, Ahold's growth objective was a $10 \%$ annual growth in earnings per share. He also announced plans to double profits and sales every five years (Het Financieele Dagblad, September 9, 1992). Under Cees van der Hoeven, the second professional CEO appointed in 1992, this was increased to a $15 \%$ annual growth in earnings per share, $10 \%$ from internal growth and 5\% from external growth (Het Financieele Dagblad, March 19, 1994). ${ }^{2}$ Ahold's professional management acknowledged the need for good investor relations to convince investors of their growth strategy and analysts to follow the company. Investor relations became an important task of the management team, especially for the CEO and CFO. Management abandoned the stakeholder approach adopted by the Heijn family and focused on shareholders. When Cees van der Hoeven signed his first annual report as the CEO in 1992, the corporate policy explicitly considered the return earned by shareholders. Ahold won multiple awards for the "best investor relations" in the Netherlands. ${ }^{3}$

A successful investor relations program was necessary to maintain the demand for Ahold shares and enable Ahold's management to pursue its aggressive growth strategy via acquisitions. Figure 2 graphs by year the number of acquisitions and divestments made by Ahold from 1989 to 2003. For Ahold's major acquisitions, Table 3 presents the acquisition's country of origin, percentage acquired, purchase price, announcement date, and the market's reaction to the announcement. Table 4 documents the year Ahold first entered a country and how it entered. During 1989-2003, Ahold acquired 97 companies and entered 26 countries for the first time.

Ahold financed its expansion primarily with debt and outside equity. Figure 3 graphs by year the new capital raised, broken down by debt and equity, for this same period, 1989-2003. Figure 3 also summarizes the annual proceeds from those debt and equity offerings. Finally, for Ahold's major equity and debt offerings, Table 5 presents the issue date, proceeds, details, bookrunners, the motivation, and the market's reaction to the announcement. Except for the Superdiplo acquisition, Ahold never paid for major acquisitions using stock swaps. Ahold typically paid cash for acquisitions through bridge financing followed by an equity and/or debt issue about four months later. The equity issues partially explain management's focus on Ahold's stock price. The higher the stock price, the smaller the equity issue needed to finance an acquisition. Because the acquisitions immediately contributed to the earnings per share, Ahold could sustain its $15 \%$ earnings growth target. We do not detail divestments.

Ahold's growth strategy differed from that of Wal-Mart and Carrefour. Ahold grew via acquisitions of store chains and then continued to operate these chains under 
their own name, local management and local identity. Carrefour and Wal-Mart had very different strategies (Coriolis Research, 2002). Carrefour expanded both nationally and internationally under one name with a large international presence. Although Carrefour attempted to expand into the US, it never succeeded. Wal-Mart also expanded domestically and internationally under one name but has a relatively small presence outside the US. As documented by analysts and others, neither the growth rate implied by Ahold's stock price nor van der Hoeven's stated annual earnings growth rate of $15 \%$ were sustainable without acquisitions, putting significant pressure on Ahold to do deals to meet growth expectations (Deutsche Morgan Grenfell, 1997, and Coriolis Research, 2001). ${ }^{4}$ In the next sections, we describe Ahold's growth strategy in detail.

\subsection{The successful growth strategy: Become the largest chain on the US East Coast}

With dominance in its domestic market, Ahold pursued its growth strategy by focusing mainly on the United States with the announced objective of being the largest supermarket chain on the East Coast. In 1977 Ahold made its first US acquisition, the BILO chain with its stores in Georgia and the Carolinas for $\$ 60$ million, followed by its second major purchase for \$ 35 million, Giant Food Stores in the Pennsylvania area, in 1981. In 1988, Ahold acquired First National Supermarkets, with operations in New England, which substantially increased its presence in the US.

In 1991, Ahold purchased the Buffalo, New York based Tops Markets with 168 stores and sales of $\$ 1.6$ billion. The stock market reacted favorably to the Tops acquisition; Table 3 shows that stock prices increased 3.3\% ( $t$-statistic=3.9). In 1994, Red Food Stores, based in Chattanooga, Tennessee, was purchased. Its 55 stores and sales of $\$ 400$ million were merged with Ahold's BI-LO chain. With 600 stores and $\$ 6.6$ billion in sales, Ahold USA was now the ninth largest grocery operator in the US.

In 1995, Ahold took over Mayfair Supermarkets, a New Jersey based chain with 28 stores and sales of $\$ 575$ million. This purchase placed Ahold, with 650 stores and sales of $\$ 8.3$ billion, a close third behind the second largest grocery on the East Coast, Winn Dixie. In 1996, Ahold made its largest acquisition, Stop \& Shop Companies, Inc., the largest chain in New England with sales of $\$ 4.1$ billion and 268 supermarkets and convenience stores. With the Stop \& Shop acquisition, Ahold was the fifth largest supermarket chain in the US and close to its goal of being the largest chain on the East Coast. As Tables 3 and 5 indicate, the market responded positively to the acquisition of Stop \& Shop and its financing. Tables 1 and 2 document the impact these acquisitions had on Ahold's sales, operating profits, assets and key financial ratios. 
There are several reasons for the success of Ahold's US strategy up to this point. First, the US retail grocery market was locally concentrated but nationally very fractured. Prior to Ahold's initiatives, the Dart group, a private drug store chain in the US run by the Haft family, attempted consolidation through acquisition. Management reacted by taking their companies private through leveraged buyouts (Chevalier, 1995a, 1995b). Chevalier (1995a, 1995b) documents lower competition in markets serviced by an LBO, which encouraged local entry and expansion by rivals. Ahold was in an excellent position to capitalize on market conditions, i.e. lower competition, and the LBO's situation, i.e. management owned companies that lacked the cash to renovate and expand. First National Supermarkets, Tops Markets and Stop \& Shop were all LBO's purchased by Ahold. Second, Ahold's approach of focusing on the East Coast through a pragmatic sequence of acquisitions, leaving local structures in place, and emphasizing backroom efficiencies was well suited for this market at this time. ${ }^{5}$

Continuing to implement its successful growth strategy, Ahold made its largest US acquisition up to that point, the publicly traded Giant Food (a different company than Giant Food Services) in 1998. Giant Food was a Maryland based chain with 173 stores, sales of $\$ 4.2$ billion and locations in Washington D.C., Maryland, Delaware, Virginia, New Jersey, and Pennsylvania. The market continued to react positively to Ahold's growth strategy, Table 3, but it was less pleased with the announcement about how it was financed, new equity and convertible bonds, Table 5. Then, in 1999 due to concerns about potential market concentration, the Federal Trade Commission blocked Ahold's acquisition of Pathmark, a 132 store chain in New Jersey, New York, and Delaware. This set back was a blow to Ahold's strategy of becoming the largest chain on the East Coast; its stock price declined by $7 \%$ on the news ( $t$-statistic=-4.4).

By this time, Ahold also faced other problems in the US. Wal-Mart started constructing Supercenters, going from zero stores in 1992 to 344 stores in 1997 with many of these stores in Ahold territory. This move put considerable pressure on Ahold's margins, both in terms of the prices the company charged and its cost structures. In 2001, Ahold moved south with the acquisition of Bruno's Supermarkets, 184 stores in Florida, Mississippi, Georgia, and Alabama. While avoiding potential problems with the Federal Trade Commission, this transaction did not impress the stock market and Table 3 shows that stock prices declined 2.5\% ( $t$-statistic=-1.8). Due to these problems, Ahold's management had to reconsider its initially successful growth strategy in the US. Analysts also questioned Ahold's growth strategy in the US (Fink, 2001). 


\subsection{Global expansion and its difficulties}

While Ahold was the dominant player in the Netherlands, it was almost impossible to penetrate the large European markets, UK, Germany or France (Perkins, 2001, and Wrigley, 2002). Europe was a gaping hole in Ahold's strategy, as it was not among the top 10 European retailers by sales (HSBC James Capel, November 12, 1999). When the two French retailers Carrefour and Promodès merged in 1999, more analysts started to question Ahold's fragmented European operation. Nevertheless, continuing its inclination towards fragmented and large acquisitions, Ahold Europe purchased a 50\% stake in ICA, Norway and Sweden, in 1999 and a 100\% stake in Superdiplo, Spain in 2000. The market was not pleased with the price paid for the acquisitions nor their financing, which consisted of new equity and convertible debt (Tables 3 and 5).

The developing world of Asia and Latin America provided opportunities for high growth, however the operating environment differed substantially from the US or Europe (Coriolis Research, 2001). Beginning in 1996, Ahold expanded outside of the US and Europe (Table 4). Ahold entered Latin America for the first time through a joint venture in Brazil. Ahold also entered Asia for the first time, China, Malaysia and Singapore in 1996, and Thailand and Indonesia in 1997.

Asia was by far the largest and most fragmented international market, with most food sales occurring outside supermarkets. It is unclear what Ahold's Asian strategy was. Carrefour was the top ranked supermarket chain in Asia. ${ }^{6}$ Carrefour was the only profitable firm in this region among its international peer group (Wal-Mart, Ahold and Carrefour), which competed with Ahold in each of the countries Ahold entered (Coriolis Research, 2001). Ahold's growth strategy in Asia failed, because the short term focus on earnings conflicted with the long horizon required to successfully enter this part of the world. Ahold withdrew from China and Singapore only three years after entering these markets in 1996, as it did not anticipate an acceptable return in the near future. ${ }^{7}$ Ahold's remaining Asian operations suffered from the after shocks of the Asian financial crisis.

Finally, Ahold expanded its operations in Latin America by organizing a series of joint ventures in Argentina, Chile, Ecuador, Paraguay, and Peru in 1998, and in El Salvador, Guatemala and Honduras in 1999 and in Costa Rica and Nicaragua in 2002. Several comments are in order: first, the sudden and extensive number of acquisitions differed from Ahold's past approach to implementing its strategy in a particular region, a steady pragmatic sequence of acquisitions and consolidation. Second, the market responded negatively overall to the Argentina purchase (see Table 3). Third, competition and the race to consolidate were intense. Carrefour was the largest supermarket chain in 
South America, the most firmly established chain from outside South America, and it was profitable. While Ahold was now the second largest chain in South America, Carrefour was twice the size ( $\$ 10.8$ billion) of Ahold and it had twice the market share (12.7\%) while operating in half as many regions (four) as Ahold with the same number of stores (about 560). Casino, another French supermarket chain, was a close third in the rankings (Coriolis Research, 2001).

In sum, Ahold was largely unsuccessful in its global expansion with the exception of the US. Although Ahold operated in four continents by 1999, it was predominantly a US and Dutch based retailer, with $57 \%$ and $31.2 \%$ of its total sales from the US and The Netherlands, respectively. Investors questioned whether the fractured acquisitions in Europe, the international acquisitions in Asia and Latin America and the constraints placed on Ahold's East Coast strategy in the United States were sufficient to sustain the $15 \%$ growth target.

\subsection{Growth as a goal unto itself: Food services}

Despite the challenges it faced in Europe, the US, Asia and Latin America, Ahold turned its main attention to the food-service industry in the US. It was a \$200 billion industry that was less consolidated than the supermarket industry, with Sysco Corporation and US Food Service, the top two companies, controlling less that 20 percent of the $\$ 160$ billion restaurant business, the largest single segment in the industry.

Ahold entered the US food-service market in March 2000 with its purchase of US Food Service (Maryland-based with sales of \$7 billion). In December 2000, it purchased PYA/Monarch (South Carolina-based with sales of \$5 billion) and in November 2002 Alliant Exchange (Illinois-based with sales of $\$ 6.6$ billion). Ahold had no experience with the food-service industry. ${ }^{8}$ The first two acquisitions doubled the size of Ahold measured by sales. The market did not react favorably to the implementation of Ahold's new growth strategy. Table 3 shows that stock prices declined by 3.1\% ( $t$-statistic=-1.3) and $4.5 \%$ (t-statistic=-3.1) on the news of the US Food Service and PYA/Monarch acquisition, respectively. ${ }^{9}$ The market also had a difficult time figuring out the implications of the financing (Table 5). Over $€ 11.6$ billion of debt and equity were issued over a two year period, 2000 to 2001.

Ahold's sudden move in the foodservice industry was generally not well understood. One analyst writes: "While this move [in the food-service industry] does open a new growth avenue for Ahold, it is a significant change in strategic directions and as such is unexpected” (HSBC James Capel, 20 March 2000). By 2002, 74\% of Ahold's 
sales came from the United States, 21.9\% from Europe, 3.4\% from Latin America and $0.7 \%$ from Asia.

\section{Ahold's collapse}

\subsection{Understanding differences between Dutch and US GAAP}

Under Dutch generally accepted principles, Dutch GAAP, goodwill purchased in an acquisition is immediately charged against stockholders' equity and does not impact earnings. ${ }^{10}$ Until 2001, US GAAP required goodwill to be capitalized on the balance sheet and amortized through the income statement over a period not to exceed 40 years. Ahold relied on acquisitions to achieve the objective of $15 \%$ growth in earnings excluding extraordinary items, currency conversions and amortization of goodwill (Table 2, see earnings per share). In this context, Ahold used Dutch GAAP to its advantage and charged as many expenses as possible against stockholders' equity. In 1993 Ahold's shares were listed on the New York Stock Exchange. Consequently, Ahold also had to report under US GAAP, which forced the firm to charge these amortization expenses to the income statement. As the number and size of acquisitions increased, and as Ahold paid more and more for its acquisitions relative to the book value of the companies, the gap between Dutch GAAP earnings and US GAAP earnings at Ahold widened. Table 6 documents the expanding difference in earnings due to goodwill from 1991 to 2003 . The table also documents the other major differences used by Ahold to increase its earnings under Dutch GAAP and meet its earnings growth objective. Dutch GAAP lost its ability to hold Ahold's management accountable for its actions associated with acquisitions.

The growing divergence between Dutch and US GAAP became clear in early 2002. Ahold reported a 16\% growth in Dutch GAAP earnings per share for 2001, excluding extraordinary items, currency conversions and amortization of goodwill. Including these effects caused the earnings per share to decline by $17 \%$ (Table 2). One month later Ahold published its annual report for the year 2001, which contained an overview of the accounting numbers under US GAAP. Under US GAAP, Ahold's earnings would have been $€ 119.8$ million instead of $€ 1,113$ million under Dutch GAAP (Table 6). In 2001, US GAAP changed the accounting for goodwill so that essentially goodwill is not amortized but is annually subjected to an impairment test, with impairments charged to the income statement. Consequently, Ahold reported over $2001 \mathrm{a}$ goodwill impairment of $€ 728$ million that was primarily due to a lower valuation for the Disco joint venture in Argentina. Under Dutch GAAP, Ahold could amortize the 
goodwill over 20 years rather than record the entire impairment charge in one year per US GAAP. ${ }^{11}$ Analysts and investors were puzzled by the large differences between Dutch and US GAAP earnings and why Ahold did not inform them when Ahold announced the Dutch GAAP results for the year 2001 (Het Financieele Dagblad, April 6, 2002). Investors began to loose confidence in Ahold's earnings numbers and the abnormal stock return equaled $-9.6 \%(t$-statistic $=-7.0)$ on the day of the news. ${ }^{12}$

\subsection{Accounting manipulations, fraud and loss of investor confidence}

The divergence between Dutch and US GAAP lowered the confidence of investors in Ahold's future, even though the firm had not violated accounting principles. In 2002 and 2003, the firm faced three serious issues: hidden contractual obligations, manipulation through the consolidation of joint ventures and a fraud with vendor rebates.

In 2002, Ahold admitted that the firm had not disclosed several material off balance sheet obligations relating to its joint ventures. The joint venture partner in Disco, the Peirano family, was having financial problems. Ahold was required to buy the family's stake in the joint venture at an inflated price if the Peirano family could not pay its debts (Het Financieele Dagblad, July 3, 2002). The abnormal return on this news was -13\% (t-statistic=-7.7). In 2002, the chairman of ICA Ahold went public with the shareholder agreement that showed Ahold was obliged to buy him and ICA Förbundet, the other partner, out in April 2004 for an estimated price of $€ 2.5$ billion. The annual report of 2001 did not mention this obligation of Ahold (Het Financieele Dagblad, October 8,2002$)$. The abnormal return on the news was $-11.1 \%$ ( $t$-statistic $=-4.3)$.

In the conference call covering 2002 first quarter results (Fair Disclosure Financial Network, June 6, 2002), van der Hoeven reported and forecasted "pro forma" earnings growth of $22 \%$ and pro forma earnings per share growth of $10 \%$ for the year. In the second quarter (Fair Disclosure Financial Network, August 29, 2002), van der Hoeven reported Ahold's first quarterly loss in 29 years and confirmed the July $17^{\text {th }}$ profit warning, expected earnings per share growth would be between 5-8\%. Finally, for the third quarter (Fair Disclosure Financial Network, November 19, 2002), van der Hoeven announced another quarterly loss and the failure of the $15 \%$ growth rate.

On Monday, February 24, 2003, Ahold announced that net earnings and earnings per share under Dutch GAAP and US GAAP would be significantly lower than previously indicated for the year ended 2002. At issue were vendor rebates, also known as promotional allowances. Food vendors, such as Sara Lee Corp. and ConAgra Food Inc., paid rebates to US Food Service for selling certain amounts of their products. US 
Food Service booked these rebates early resulting in inflated promotional allowances and earnings. Ahold's press release gave a preliminary estimate of $\$ 400$ million. In the end, the number was $\$ 850$ million. The overstatements of the income required the restatement of Ahold's financial statements for fiscal years 2000 and 2001 and the first three quarters of fiscal year 2002 (Table 7).

In addition, the company announced that four current joint ventures (ICA, Bompreço, Disco, Jerónimo Martins Retail) and one former joint venture (Paiz Ahold) should not have been fully consolidated in its financial statements. The full consolidation of these joint ventures was based on letters stating Ahold had control over these joint ventures. With stated control, Ahold recorded $100 \%$ of revenue and expenses of the joint venture and $100 \%$ of the net income under Dutch and US GAAP, which boosted Ahold' sales and earnings (Ahold's objective was doubling sales every five years). The problem was the existence of secret side letters, known as comfort letters, nullifying the control letters. These side letters stated that Ahold was not in control of the joint ventures and were meant to "comfort" the other joint venture partners by ensuring them that their shares would not be worth less due to the loss of control to Ahold. Commencing fiscal year 2002, Ahold was forced to proportionally rather than fully consolidate these joint ventures under Dutch GAAP and US GAAP. ${ }^{13}$

Table 7 details the adjustments made to the net income previously reported under Dutch GAAP for 2000 and 2001; Table 6 documents the reconciliation of the restated Dutch GAAP numbers to US GAAP. Earnings in 2000 started at $€ 1.115$ billion and ended at $€ 442$ million after restatements and US GAAP adjustments. For 2001, earnings dropped from a $€ 1.113$ billion profit to a €254 million loss. Finally, for 2002, loses started at $€ 1.2$ billion and ended with a $€ 4.3$ billion loss. ${ }^{14}$

The supervisory board announced the resignations of Chief Executive Officer, Cees van der Hoeven, and Chief Financial Officer, Michael Meurs. The chairman of the supervisory board was given responsibility for the conduct of the management board and the affairs of the company. The company deferred its announcement of the full year results for 2002. Ahold's auditors suspended the 2002 year audit pending completion of its investigations.

The markets reacted violently; Figure 1 documents the drop in equity prices. The abnormal return on the day of announcement was $-59.4 \%$ ( $t$-statistic=-23.1). The bond market reacted in a similar manner; in the sterling market Ahold's bonds dropped 28.3\% and in the euro market, the bond prices decreased 27.4\%. Standard \& Poor's responded immediately by downgrading Ahold's credit rating from BBB to junk. The next day Moody's downgraded Ahold from Baa3 to B1. 


\section{Corporate governance}

\subsection{Code of corporate governance}

In this section, we analyze Ahold's corporate governance structure and ask what went wrong. First principles of corporate governance were generally understood in the academic literature (Hart, 1995) and in the policy arena where corporate governance codes addressing best practices appear in the 1990s. Because best practices are generally accepted and commonly known, they form a benchmark for evaluating Ahold's corporate governance. We use the Organisation for Economic Cooperation and Development's (OECD) Principles of Corporate Governance (1999) as our benchmark, Table 8, the standard by which other international codes are compared. ${ }^{15}$ Shareholder rights, the role of supervisory boards (and non-executive directors in unitary systems), and disclosure and transparency are important aspects of the OECD code. For example, shareholders are to be informed and have the right to elect members of the board, vote on fundamental corporate changes, and vote in general shareholder meetings (in person or in absentia). The market for corporate control should function without anti-takeover devices. General and institutional shareholders should consider the implications of their votes. The board should exercise objective judgement independent of management and devote sufficient time to the firm. The board's functions include guiding corporate strategy, ensuring the integrity of financial reporting, disclosure and communication, and selecting, overseeing and compensating key executives.

We evaluate Ahold's ownership and control structure, management board, supervisory board and incentive compensation. We also consider the traditional gatekeepers in the financial markets, Ahold's house bank, financial analysts and auditor.

\subsection{Ownership and control structure}

The role of shareholders in Ahold depends on the ownership structure, i.e. ownership distribution and legal constructions that limit shareholder influence. Beginning in 1948 with the family through 2001 with professional management, the family and management adopted all the defenses available to Dutch companies to obtain and maintain complete control of Ahold: founder/priority shares, preferred shares with the option to dilute $100 \%$ in case of a hostile takeover, the structured regime, binding nominations and certificates (see Table 9). ${ }^{16}$ These defenses negate the ability of shareholders to monitor management on a day to day basis by depriving shareholders of their voting rights and the ability of 
the market for corporate control to discipline management via a takeover. The legal structures and takeover defenses introduced under the Heijn family and later capitalized upon by van der Hoeven to maintain control of Ahold undermined the disciplining power of the market for corporate control, prevented blockholder monitoring by denying institutional shareholders their voting rights and transferred decision rights from shareholders to the supervisory board. In the remainder of this subsection we will detail Ahold's ownership structure and the obstruction of shareholder influence.

Ahold was a privately held family company owned by Albert Heijn from its start in 1887 until 1948. After World War II, the firm faced two problems, i.e. family succession and accessing needed capital for expansion, which were both solved by an initial public offering. The firm Albert Heijn, Ahold's predecessor, was listed in Amsterdam in 1948 with the two sons, Gerrit and Jan Heijn, holding fifty percent of the outstanding shares (de Jager, 1995, p.108). In the public offering, the two sons received founder shares, also referred to as priority shares (see Table 9). These shares gave the sons the right to make binding nominations for all the members on the management board and one member on the supervisory board.

The family firm operated under a two-tier board structure, with a management board monitored by a separate institution, the supervisory board. Through the 1960s and 1970s, there were frequent equity offerings which the family did not participate in. While this reduced the family's ownership, the family maintained control of Ahold via the founder shares. In the early 1970s, two legal constructions were adopted by Ahold. First, a major revision of Dutch company law, applicable for Dutch companies with more than 100 employees, a legally installed work council, and book value of shareholders' equity in excess of $€ 11.4$ million, superseded the founder shares and required Ahold to organize under the "structured regime" in 1972. This regime weakened the powers of shareholders, see Table 9. Under this regime the supervisory board takes over the following powers from shareholders: the establishment and approval of the annual accounts, the election of the management board, and the election of the supervisory board itself (called co-

optation). The supervisory board also has authority over major decisions made by the management board. The law prescribes that the supervisory board be "independent" of the company and serve the firm's interest. However, the family effectively controlled Ahold via the grandfathered management board, which consisted of the two sons of Jan Heijn, Ab and Gerrit Jan, and the grandfathered supervisory board, previously controlled by the family via founder shares.

The second construction was adopted in 1973 when Ahold set up the Stichting Ahold Continuïteit (SAC, Foundation Ahold Continuity), which is an anti-takeover 
defense. This foundation owns an option to call preferred shares with a nominal value that equals the current capital. ${ }^{17}$ In case of a takeover threat the foundation exercises the option and places the preferred shares - of which only $25 \%$ has to be paid - with friendly parties. This dilutes the stake of a hostile bidder, Table 9. SAC is friendly to incumbent management; the defense has no effect until the option is exercised. ${ }^{18} 19$

By 1989, when professional management took over the positions of the Heijn family in the board, family ownership had declined to $7.3 \%$ (see Table 10, which details Ahold's major blockholders starting in 1989). In 1993, several Heijn family members needed funds for other ventures. The family found a US investor willing to pay a good price on a no-name basis. However, this investor would become a serious blockholder. To keep control over Ahold, van der Hoeven wanted ABN-Amro to purchase the shares, de Jager (1997, p.239). The shares were sold to ABN-Amro, who then placed them with institutional investors to ensure a dispersed ownership structure without blockholder monitoring. In 1996, van der Hoeven again avoids blockholder monitoring in the dissolution of Ahold's co-operative venture, European Retail Association (ERA). ${ }^{20}$ This involved the sale of Ahold's stakes in its partners Argyll and Casino. Argyll and Casino also sold their respective stakes in Ahold by placing them with four institutional investors, pension fund ABP and bank/insurance companies Achmea, Fortis, and ING. Finally, van der Hoeven ensured a dispersed ownership structure by paying for Ahold's acquisitions in cash rather than stock swaps.

In 1996, simultaneously with the sale of the Argyll and Casino stakes, van der Hoeven announced the issuance of preferred financing shares, a type of security not used before; €59.4 million was raised from friendly institutional investors Achmea, Aegon, Fortis and ING in June 1996. The investors qualified for tax exemption because they each owned more than 5\% stakes in Ahold. By 1997, 34\% of Ahold's shares were owned by institutions with holdings in excess of $5 \%$, Table $10 .^{21}$ Van der Hoeven avoided blockholder monitoring by the institutional investors via certification of the preferred shares. Certificates of preferred shares were stripped of their voting rights, with the voting rights under control of the foundation Stichting Administratiekantoor Preferente Financieringsaandelen Ahold (SAPFA). This foundation is not related to the SAC foundation mentioned earlier. Because these preferred shares are issued at par value, which was lower than the economic value, the foundation received disproportionate voting power, i.e. $19 \%$ of the votes while the economic value was $6 \%$ of total equity (Het Financieele Dagblad, June 21, 1996). These institutional investors agreed with this construction because they had little incentive to monitor Ahold as the preferred dividends secured their yearly returns. SAPFA was set up by management to control the votes tied 
to the certificates of preferred shares held by the institutional investors, Table 9, via the board of SAPFA. ${ }^{22}$ The workings of SAPFA are best illustrated by the first annual shareholder meeting held after the refinancing on May 6, 1997. At that time, there were 168 million ordinary shares outstanding and 40 million cumulative preferred shares outstanding, entitled to 208 million votes. With all shareholders present the preferred shares had 19\% of the votes. In the 1997 meeting, there were 823 shareholders present, representing 63 million shares. SAPFA controlled 63\% of the votes with its 40 million preferred shares cast by the chairman of the foundation. During the meeting the chairman explained that the board of the foundation in a meeting held before the annual meeting decided to vote favorable on all management proposals.

Finally, in the shareholders' meeting of May 15, 2001, Ahold abolished the structured regime, which had no impact on shareholder influence, Het Financieele Dagblad (May 16, 2001). ${ }^{23}$ The Dutch Social-Economic Council, the principal advisory group to the government, had just made its recommendations to parliament about the future of the structured regime. Under the structured regime, one of the proposals was that $1 / 3$ of the supervisory board members be nominated by the work council. Another proposal was to have board members nominated by the supervisory board, with shareholders having the right to vote down the proposal with a 2/3 majority representing $1 / 3$ of the capital. Ahold changed its statutes and included so-called binding nominations, which implies that the supervisory board does all the nominations and these can only be rejected with $2 / 3$ majority representing $1 / 2$ of the capital. By eliminating the structured regime and adopting the new statute, Ahold eliminated supervisory board nominations from the workers and increased the threshold for rejecting supervisory board nominations.

\subsection{Management board}

Prior to 1987 the management board consisted primarily of Ab Heijn, CEO, and his younger brother Gerrit Jan Heijn. Given the firm's growth, the lack of a long-term family heir and the need for professional management, the Heijn brothers expanded the board to seven members by 1987, see Table 11; van Dun, a personnel specialist; Ahlqvist, the first professional marketer on the board; Zwartendijk who was brought by Ahlqvist in order to run the production firms in Ahold; Cees van der Hoeven, CFO, and Pierre Everaert, responsible for foreign activities. The transition to professional management was accelerated by the kidnapping and murder of Gerrit Jan Heijn in late 1987 and early 1988. Gerrit Jan was expected to succeed Ab and keep the firm under family control for another 
three years. Ab wanted to continue as the CEO when he reached mandatory retirement in 1989, but this plan was voted down by the other members of the management board (Smit, 2004, p.98-99). Ab Heijn retired in 1989 and moved to the supervisory board.

There were two management board members who were candidates for the CEO position. Cees van der Hoeven was the company’s CFO with 15 years experience with Royal Dutch/Shell. His opponent, Pierre Everaert was an engineer with international experience at Goodyear and Générale Biscuit before joining Ahold. Cees van der Hoeven won the vote for CEO within the management board. However, members of the supervisory board and Ab Heijn preferred and appointed Pierre Everaert as CEO in September 1989. In December 1992, Everaert announced his departure to Philips, the large Dutch consumer electronics firm. Choufoer, chairman of Ahold's supervisory board, agreed that van der Hoeven would not only become the new CEO but also retain his CFO position. With Evereart's resignation, van der Hoeven became both CEO and CFO. This is a breakdown in controls. By 1998 van der Hoeven had surrounded himself with managers who were loyal to him. Van Dun had retired. There were three additions, one insider Andreae from Albert Heijn for his retailing experience, and two from the outside, Meurs from ABN-Amro, the CFO in waiting, and Moerk for his international business background.

Over the four year period, 1998 to 2002, there was a 50\% turnover in the management board. Van der Hoeven (now only CEO), Andreae (Albert Heijn) and Meurs (CFO) were still on the board. New members were de Raad (formerly of SHV and German retailer Metro), Grize (management from Stop \& Shop), and Miller (management from US Food Service). In addition, Noddle, management from Giant Food Stores, came on and went off the board during this time period. The presence of former management of recent acquisitions, Grize, Miller and Noddle, promoted loyalty, because these managers were promoted to the board of a much larger firm in a very uncertain situation. It is common for managers to lose their jobs when taken over. Further, these board members monitored the subsidiaries they previously managed. Though consistent with Ahold's strategy of keeping acquired management, it represents poor internal control over management.

The management board was not effective for two reasons. First, all members owed their positions to van der Hoeven. After a period of high turnover, the board consisted of people internally promoted from subsidiaries (Grize, Miller, Noddle and Andreae) or staff functions (Meurs). The second characteristic is van der Hoeven's personality. Earlier clinical studies by Dial and Murphy (1995) and DeAngelo and DeAngelo (2000) document similar situations in which the strategic directions in former 
family-controlled firms are determined by a powerful professional CEO. DeAngelo and DeAngelo argue that managerial decisions reflect the manager's mindset, personal values and experience. Van der Hoeven is described by Smit (2004) and Ab Heijn (de Jager, 1997) as a strong and persuasive personality. In addition to several awards for Ahold (Dutch investor relations, worldwide retailer), van der Hoeven also received personal awards, like "CEO of the year" (Het Financieele Dagblad, January 12, 2000). The combination of van der Hoeven's power in the management board, his successes in the 1990s and his personality had a major impact on Ahold's strategies.

\subsection{Supervisory board}

The supervisory board failed to adapt to a professionally managed firm with a dispersed ownership structure. The OECD structure and responsibilities for supervisory boards imply that the problems documented for Ahold are primarily the board's responsibility. Supervisory board members must be independent, capable and devote sufficient time to the firm. John and Senbet (1998) review the literature on board effectiveness and confirm the relevance of these board characteristics. The supervisory board is especially important in the Netherlands, where either by Dutch law or by company statutes in the case of Ahold after 2001 key decision rights of shareholders are transferred to the supervisory board, Table 9. Ahold's supervisory board was not independent due to the presence of former managers and supervisors with conflicting interests with other stakeholders. Moreover, many board members were overcommitted.

Members of Ahold's supervisory board with their relevant professional experience are detailed in Table 12. Independence from the management board is limited when former managers become supervisors. The 1987 board had former CFO Vethaak as a member and former CEO Ab Heijn was a member from 1990 to 1997. The role of Heijn

was very passive. ${ }^{24}$ Starting in 1993, supervisory board members were recruited from the management of acquired firms: Bogomolny was the former CEO of First National Supermarkets. In 2001, Fahlin (former ICA) entered the board, as did Tobin. Tobin was the former manager of Stop \& Shop and had been in Ahold's management board starting in $1998 .{ }^{25}$

Several board members had ties with institutions related to Ahold, which lead to conflicts of interest with these stakeholders. Nelissen, a board member from 1987 to 2001, is particularly interesting; he was the CEO of Amro, one of Ahold's main banks. When Amro and ABN merged in 1990, Nelissen became CEO of the combination until his retirement in 1992. After retiring he became a member of the bank's supervisory 
board. Nelissen was also on the board of Ahold's auditor, Deloitte. Through Kreiken and Choufoer, Ahold had interlocking directorates with two other Dutch financial institutions, Nationale Investeringsbank and ING. Choufoer was also from Royal Dutch/Shell, van der Hoeven's employer for fifteen years. Sir Perry was the former CEO of Unilever, a major supplier of consumer goods to Ahold.

The board members were generally qualified based on experience and background. One exception should be noted. Several politicians served on Ahold's board: Rempt-Halmmans de Jongh, de Koning, van Kemenade and Schneider. While there were no conflicts of interest with other businesses, their business expertise was most likely less than other members. ${ }^{26}$

Ahold had board members with enormous board portfolios, which limited their commitment to the firm. For example, in 1987, five of the nine board members served on other companies' supervisory boards, three are overcommitted: Choufoer (with 4 additional supervisory board positions), de Soet (with 18) and Nelissen (with 18). In 1998, four of the seven supervisory board members are overcommitted. The new chairman, de Ruiter, had 17 other supervisory board positions including Royal Dutch/Shell. ${ }^{27}$

There is very little information on committees and their membership. The 19972001 Dutch annual reports indicate that the supervisory board had a functioning audit committee, a remuneration committee and a selection and nomination committee. However, no members were listed. ${ }^{28}$

As a proxy for its power, the relative size of the supervisory board is important (John and Senbet, 1998). In 1987, when the Heijn brothers were still active, the ratio of supervisory to management board members was nine to seven (Table 12). In 1993, the ratio increased, nine to four, and in 1998 and 2001, the ratio dropped, seven to six. While this proxy is inconclusive for Ahold, anecdotal evidence suggests that the management board had significant influence over supervisory board appointments and its decisions, dating back to the Heijn family and the influence of its founder shares. Shivdasani and Yermack's (1999) data suggest that in such situations, CEOs select board members that are loyal to them. In the case of Ahold, the family had always controlled the supervisory board by its grandfathered members and the co-optation under the Dutch company law that allowed the supervisory board to effectively choose its own members. Professional management continued this tradition in which Ahold's management board provided the nominations for the supervisory board. ${ }^{29}$

\subsection{Incentive compensation}


Option-based incentive schemes align interests and encourage professional managers to behave in the interest of shareholders. Executives at the level of Ahold's management board negated the long-term incentive effects of ownership by exercising their options and immediately selling the shares. This represents a stark breakdown in an incentive structure (overseen by the supervisory board). If management had any doubts about an acquisition or accounting policy, the compensation incentives (bonuses and stock options based on earnings growth) certainly appeased those doubts. Ofek and Yermack (2000) confirm this finding in general.

We focus on stock options at the executive and board level for two reasons: aggregate stock option information is available and reliable and for Ahold, stock options were an integral part of its incentive structure. Table 13 details Ahold's stock option information from 1987 through 2003. For each year when available, the information includes the beginning number of options outstanding, options granted, exercised and cancelled, average price of the options exercised, the price range of the options outstanding at year's end, the average market price of the stock, and the number of employees under the plans (in the note below Table 13). Compensation (salary, bonus and pensions, excluding stock options) is presented in the second and third columns of the table, broken down by supervisory and management board. To provide a perspective on the potential influence of the options, the last two columns present the net proceeds from the options exercised and the ratio of the net proceeds to the management board's cash compensation.

Through 2001, bonuses and options were based on annual income per share growth (Form 20-F, 2002). Starting in 2002, the bonuses were based on improvement in Economic Value Added (EVA). For the Dutch management board members, the target was based on improvement in EVA for the overall company. For the US management board members, their target was weighted $10 \%$ on improvement for Ahold over all and $90 \%$ on improvement for their respective US areas of responsibilities. The bonus paid for meeting the targets was $125 \%$ of the base salary. Stock option awards were still based on growth in basic net income after deducting preferred dividends (Form 20-F, 2002).

In 2002, the management board held about 2 million options; van der Hoeven had about half of those options. However, the management board owned very few shares, 188,000, and van der Hoeven ranked a distant third among the management board with 34,000 shares. In June 2002, the management board announced their intention to purchase shares in order to support and improve the stock price. As of September 2002, 
only de Raad, Andreae and Meurs had bought shares. The supervisory board held 5,200 shares with Fahlin, ICA management, holding 2,000 of those shares.

If managerial ownership with its long-term incentives was the goal of the stock option plan (overseen by the remuneration committee of the supervisory board), it was not working for top management at Ahold. Management essentially sold the shares obtained from these plans. A simple measure to gauge the incentive effects of the options exercised is the ratio of the net proceeds from the exercised options compared to the management board's other compensation (salary, bonus and pensions). ${ }^{30}$ During the 1987 to 1997 period (Table 13), a period when options were available to only a relatively few in the company, the ratio for 1988 was $10 \%$, from 1989 to 1995 it ranged from $70 \%$ to $160 \%$, in 1996 and 1997 it was $660 \%$ and $750 \%$ respectively. ${ }^{31}$

\subsection{Gatekeepers in the financial markets}

This section addresses the role of the traditional gatekeepers in the financial markets, the final component of corporate governance that we consider. ${ }^{32}$ Ahold's influence is prominent in its relationship with its house bank and with analysts.

\subsubsection{House bank}

Ahold used ABN-Amro as its main bank. Before ABN and Amro merged in 1990 to form ABN-Amro, Ahold had the most loans with Amro and the second most loans with ABN (Het Financieele Dagblad, April 12, 1990). Nelissen, past CEO of ABN-Amro and supervisory board member, was on Ahold's supervisory board. Meurs, Ahold's new CFO, was a former employee of ABN-Amro. In 1997, van der Hoeven was appointed to the supervisory board of ABN-Amro and in 2001 to its audit committee. ${ }^{33}$ Among Meurs, Nelissen and van der Hoeven, strong personal relations were present at the highest levels. ABN-Amro's 2002 annual report disclosed that van der Hoeven had a personal loan of 5.088 million euro with this bank (Het Financieele Dagblad, March 21, 2003). More importantly, ABN-Amro frequently participated in the bridge financing of Ahold's acquisitions and the debt and equity offers ultimately used to finance those acquisitions. ${ }^{34}$ The multiple relations between ABN-Amro and Ahold indicate strong bilateral relationships. ABN-Amro benefited from these relations because of lending and the underwriting fees. 


\subsubsection{Analysts}

Ahold set up an extensive investor relations program in an attempt to encourage investors to buy Ahold's stock and analysts to follow the company. Financial analysts have the analytical skills to critically evaluate Ahold's strategies and provide more objective information to market participants. Figure 4 graphs the analysts' recommendations for Ahold from 1993 to 2003. There were 490 recommendations during this period. Analysts were generally optimistic about Ahold until October 2002, when on average analysts downgraded Ahold. This downgrade was before the fraud and matched Ahold's abandonment of its $15 \%$ growth target and its first losses in 30 years.

The most pessimistic recommendations came from HSBC James Capel; it had no affiliations with Ahold. For example in one report HSBC questioned the strategy of Ahold by unmasking five myths: accelerated earnings growth, a very solid company, the best supermarket on the globe, strong exposure to fast growing emerging markets, and a shareholder friendly company (HSBC James Capel, July 1, 1997). Not surprisingly, the most positive recommendations came from ABN-Amro. This is in line with the multiple relations the bank had with Ahold, see section 4.6.1.

\subsubsection{Auditors}

The forensic audit of PriceWaterhouseCoopers documented lax internal controls and poor financial and accounting practices on the part of Ahold in the US. A total of 275 out of 470 accounting irregularities could be related to weak internal controls. In implementing its growth strategy in the US, Ahold ignored one of the basic tenants of control in a decentralized organization with performance based compensation, strict internal, financial and accounting controls across the organization. The forensic audit also showed that throughout Ahold there was a lack of knowledge about Dutch GAAP and US GAAP and consequently the disciplining role of US GAAP on management's activities.

Deloitte \& Touche, Ahold's auditor detected the problems at US Food Service at an early stage. Deloitte conducted a due diligence investigation at the time of the acquisition of US Food Service, 2000. Deloitte reported that the system used to record vendor allowances at US Food Service was very opaque (Smit, 2004, p.261). Deloitte also uncovered the scale of Ahold's accounting irregularities as part of its 2002 year-end audit. Moreover, Deloitte \& Touche was not informed about the conflicting comfort letters; they were only shown the side letters that stating Ahold had full control over the joint ventures. In litigation, no rulings have yet been made, in which the auditors have been held responsible for Ahold's losses. 


\section{Lessons learned}

In this clinical study, we examine Ahold and provide an explanation for the ultimate failure of its growth strategy via acquisitions and the substantial losses incurred by its shareholders. Analyzing recent merger and acquisition failures, Moeller, Schlingemann and Stulz (forthcoming) suggest their evidence is consistent with Jensen's view (2004) that high equity values put pressure on management to sustain growth levels and gives management more discretion to make poor acquisitions that value growth over shareholder value.

For Ahold, it was management's successful investor relations program that maintained the company's stock price and placed substantial pressure on management to sustain its growth objective. While its initial strategy was successful, Ahold was required to alter its strategy due to the unfavorable anti-trust ruling in the US and the increased international competition in the retail grocery segment of its business. Poor corporate governance (absence of internal as well as external oversight of management's strategy and implementation) was a significant factor in Ahold's collapse.

Beginning with the family and continuing under professional management, the family and management adopted all the defenses available to Dutch companies to obtain and maintain complete control of Ahold. The financing method used by van der Hoeven put voting control of the institutional investors' holdings in a foundation, whose board was strongly influenced by Ahold's management. These defenses negated the ability of shareholders to monitor management on a day to day basis by depriving shareholders of their voting rights and the ability of the market for corporate control to discipline management via a takeover.

This control allowed management to essentially capture the supervisory board, which was the last institution that stood in the way of management's complete control of the company. The supervisory board is where the growth objective and strategy should have been debated, the strategy's implementation monitored and oversight maintained. With the dominant tradition of the management board and the supervisory board's over commitments and conflicts of interest, the supervisory board failed in its transition to a professionally managed firm with dispersed ownership. CEO van der Hoeven then had control of the management board, the incentive compensation system and the firm. Since management held very little of the company's stock, the incentive compensation plans with their emphasis on earnings growth aggravated the other shortcomings and provided a direct motivation for management valuing growth over shareholder value. This is in 
addition to Jensen's argument (2004) that high firm value gives management more discretion to make poor acquisitions that value growth over shareholder value.

Since its collapse, Ahold has taken corporate governance more seriously. Ahold established the position of Chief Governance Counsel on the management board to improve corporate governance policies and practices, legal compliance and adherence to ethical and social standards, see Table 11. The new chairman and two new finance members of the management board have no previous associations with Ahold and are not Dutch citizens. Since 2003, except for Grize, former Shop \& Shop management, there are no longer any management board members from past acquisitions. Since 2003 (Table 12), the supervisory board replaced the two members associated with past acquisitions and the former Unilever chairman.

Ahold adopted a more open structure and gave shareholders more of a voice (Business Week, July 18, 2004). Shareholders are entitled to approve important decisions such as acquisitions and divestments; they can initiate and propose resolutions on a wider range of topics. The company reduced the percentage of votes potentially cast at the general meeting by the preferred financing shares from $19 \%$ to $6 \%$ of total votes outstanding, which represents its economic value. The company set a maximum number of options to be granted to the CEO and other board members. Internal controls are also improving: the internal audit committee now reports to the audit committee members of the supervisory board instead of the CEO (as required for the Sarbanes-Oxley Act and under the NYSE listing requirements).

Could Ahold or a situation similar to Ahold have been avoided by the adoption and enforcement of a strong code of corporate governance, for example the OECD code in Table 8? The answer is that the probability of avoiding an Ahold or a situation similar to Ahold would be much higher with adoption and enforcement of the code. Except for voting by proxy, which is not allowed under Dutch law, professional management could have voluntarily adopted the OECD code for Ahold. Why didn't they? Relative to other areas with self-regulation, the track record of self-regulation in corporate governance is not encouraging (Conglianese, Healey, Keating and Michael, 2004). Enforcement is difficult and bonding does not seem to work that successfully (due possibly to credibility issues). Moreover, the rent protection theory of Bebchuk (1999) suggests that managers are unlikely to give up control in countries with weak legal shareholder protection, such as the Netherlands and the rest of Continental Europe, where managers can enjoy large private benefits of control.

Could shareholders rely on current Dutch corporate law to protect their future interests? After Ahold's collapse, the Tabaksblat Committee's set of principles and best 
practices has become a formal part of Dutch law and requires firms to comply or explain their non-compliance. However, there is no direct legal enforcement or monitoring and takeover defenses such as certificates are still legal. The Committee gives shareholders the primary monitoring responsibility; however, shareholder rights are not directly reinstated. Thus, there is nothing in the principles or best practices that would prevent a firm's management from using existing law to obtain or maintain its control over a company.

Within the confines of a given regulatory structure, the general lesson from Ahold is not to underestimate the ability of management to obtain and maintain control over a firm at the expense of its shareholders. This is important for Europe where there is concern about the performance of majority and/or family dominated firms that are publicly traded (Faccio and Lang, 2002). There is also an argument made that to increase performance these firms should consider moving to a dispersed ownership structure with professional management. Ahold has shown that the absence of a family or major blockholder in combination with unconstrained professional management can be bad for corporate governance and in the case of Ahold devastating for the continuity of the firm and its performance. 


\section{References}

Agrawal, A., Knoeber, C.R., 1996. Firm performance and mechanisms to control agency problems between managers and shareholder. Journal of Financial and Quantitative Analysis 31, 377-397.

Bebchuk, L.A., 1999. A rent-protection theory of corporate ownership and control. Working paper, Harvard Law School.

Cadbury Committee, 1992. The Financial Aspects of Corporate Governance. Burgess Science Press, London.

Chevalier, J., 1995a. Capital structure and product-market competition: empirical evidence from the supermarket industry. American Economic Review 85, 425435.

Chevalier, J., 1995b. Do LBO supermarkets charge more? An empirical analysis of the effects of LBO’s on supermarket pricing. Journal of Finance 50, 1095-1112.

Coglianese, C., Healey, T., Keating, E., Michael, M., 2004. The role of government in corporate governance. Working paper, John F. Kennedy School of Government, Harvard University.

Coriolis Research, 2001. Retail Supermarket Globalization: Who's Winning? Coriolis Research, Auckland.

DeAngelo, H., DeAngelo, L., 2000. Controlling stockholders and the disciplining role of corporate payout policy: a study of the Times Mirror Company. Journal of Financial Economics 56, 153-207.

De Jager, J.L.,1995. Arm en Rijk kunnen bij mij hun Inkopen doen; De Geschiedenis van Albert Heijn en Koninklijke Ahold. Tirion, Baarn.

De Jager, J.L., 1997. Albert Heijn; De Memoires van een Optimist. De Prom, Baarn.

De Jong, A., DeJong, D.V., Mertens, G., Wasley, C.E., forthcoming. The role of selfregulation in corporate governance: evidence and implications from the Netherlands. Forthcoming in Journal of Corporate Finance.

De Jong, A., Röell, A., forthcoming. Financing and control in the Netherlands: an historical perspective. In Morck, R. (Ed.), The History of Corporate Ownership: The Rise and Fall of Great Business Families. NBER Conference Volume, University of Chicago Press, Chicago, IL.

Demsetz, H., 1983. The structure of ownership and the theory of the firm. Journal of Law \& Economics 26, 375-390.

Dial, J., Murphy, K.J., 1995. Incentives, downsizing, and value creation at General Dynamics. Journal of Financial Economics 37, 261-314. 
DiGeorgio, R., 2002. Making mergers and acquisitions work: what we know and don't know - part I. Journal of Change Management 3, 134-148.

Easterbrook, F.H., 1984. Two agency-cost explanations of dividends. American Economic Review 74, 650-659.

Faccio, M., Lang, L.H.P., 2002. The ultimate ownership of Western European corporations. Journal of Financial Economics 65, 365-395.

Ferris, S.P., Jagannathan, M., Pritchard, A.C., 2003. Too busy to mind the business? Monitoring by directors with multiple board appointments. Journal of Finance 58, 1087-1111.

Fink, R., 2001. Royal ambition: with supermarkets on four continents, Royal Ahold offers lessons in cross-border acquisitions. CFO Magazine (April 1), 46.

Hart, O., 1995. Corporate governance: some theory and implications. The Economic Journal 105, 678-689.

Jensen, M.C., 1986. Agency costs of free cash flow, corporate finance, and take-overs. American Economic Review 76, 323-329.

Jensen, M.C., 2004. Agency costs of overvalued equity. ECGI Finance Working Paper no. 39/2004.

John, K., Senbet, L.W., 1998. Corporate governance and board effectiveness. Journal of Banking \& Finance 22, 371-403.

Moeller, S.B., Schlingemann, F.P., Stulz, R.M., forthcoming. Wealth destruction on a massive scale? A study of acquiring-firm returns in the recent merger wave. Forthcoming in Journal of Finance.

Ofek, E., Yermack, D., 2000. Taking stock: equity-based compensation and the evolution of managerial ownership. Journal of Finance 55, 1367-1384.

Organisation for Economic Co-operation and Development, 1999. OECD Principles of Corporate Governance.

Perkins, B., 2001. The European retail grocery market overview. British Food Journal 103, 744-748.

Peters Committee, 1996. Corporate Governance in Nederland; een Aanzet tot Verandering en een Uitnodiging tot Discussie.

Shivdasani, A., Yermack, D., 1999. CEO involvement in the selection of new board members: an empirical analysis. Journal of Finance 54, 1829-1853.

Smit, J., 2004. Het drama Ahold. Balans, Amsterdam.

Tabaksblat Committee, 2003. The Dutch Corporate Governance Code; Principles of Good Corporate Governance and Best Practice Provisions. 
Voogd, R.P., 1989. Statutaire Beschermingsmiddelen bij Beursvennootschappen, Ph.D. dissertation, University of Nijmegen.

Wrigley, N., 2002. The landscape of pan-European food retail consoldidation. International Journal of Retail \& Distribution Management 30, 81-91. 


\section{Notes}

${ }^{1}$ The main sources for our description are Ahold's annual reports, SEC filings, press releases and minutes of shareholder's meetings, the Dutch financial daily (Het Financieele Dagblad) and analyst reports of various banks. Our sources also include de Jager (1995), a description of Ahold's history and de Jager (1997) which are Ab Heijn's memoirs; both are written in co-operation with the Heijn family and Ahold. Smit (2004) also describes Ahold's history, with an emphasis on the most recent period. The content of this book is based on public sources and interviews. The interviewees remain anonymous and the author mentions that the conclusions are based on at least two sources.

${ }^{2}$ Van der Hoeven is always somewhat vague about his definition of earnings and earning per share (analysts are also confused about his definition). A working definition is one based on Dutch generally accepted accounting principles (earnings excluding extra ordinary items, goodwill and currency effects).

${ }^{3}$ Ahold was chosen by investors, analysts and the financial press as the best company during the "Day of the Share”. From 1990 to 2001, Ahold won this award seven times (Het Financieele Dagblad, October 29, 1999 and February 2, 2003).

${ }^{4}$ As the base increases, it becomes more difficult to achieve $15 \%$ growth of earnings, and so Ahold needs larger and larger deals. One analyst has written: "Ahold remains addicted to acquisitions for growth" (HSBC James Capel, September 15, 2000).

${ }^{5}$ The strategy implemented by Ahold matches the two Porter attributes most often found with successful acquisitions; acquisitions that rely on transfer of skills and shared activities (DiGeorgio, 2002).

${ }^{6}$ We exclude Japanese chains in this ranking; while larger, they have not been successful in exporting their business model outside of Japan.

${ }^{7}$ One analyst described this move as: "entering in haste and then repenting later when they go wrong" (HSBC James Capel, March 20, 2000).

${ }^{8}$ DiGeorgio (2002) documents that strategies based on Porter's diversification or restructuring motives have a high failure rate compared with those based on transfer of skills and shared activities.

${ }^{9}$ Ahold's share price was very volatile around this period, which is reflected in the relatively low $t$ statistics.

${ }^{10}$ A working definition for goodwill is the difference between the purchase price and the book value of the acquired company's stockholders' equity adjusted for asset revaluations at the time of the purchase. Asset revaluations are the difference between the appraised value of the assets and their book value.

${ }^{11}$ Due to a new accounting guideline (RJ 500) issued by the annual reporting council (RJ), the Dutch accounting standard setter, Ahold changed its accounting policy with respect to goodwill. Beginning December 1, 2000, in line with RJ 500, goodwill is capitalized and amortized over its useful life with a maximum of 20 years. Until then Ahold expensed all goodwill against stockholders' equity.

${ }^{12}$ In addition, in a footnote in the annual report Ahold stated that it had been counting smaller acquisitions as organic growth for years.

${ }^{13}$ The company also announced that it has been investigating, through forensic accountants, the legality of certain transactions and the accounting treatment thereof at its Argentine subsidiary Disco.

${ }^{14}$ For 2001, there was a $€ 588$ million reduction in earnings under US GAAP to reflect the difference between the share in the loss of joint ventures under Dutch GAAP and US GAAP. This difference primarily relates to a goodwill impairment loss of $€ 505$ million in Disco; the $€ 505$ million impairment was reclassified by Ahold from the goodwill adjustment in the original statements to the joint venture adjustment in the restated numbers. There was a further $€ 311$ million reduction in restated Dutch GAAP earnings due to US GAAP reporting requirements for Ahold's sale and leaseback, derivatives and options transactions. For 2002, there was a €3.2 billion charge to earnings under US GAAP due to goodwill amortization and impairment with $€ 1.85$ billion from US Food Service.

15 The OECD code was established in 1999 and updated in 2004. The ideas reflected in the code are already present in the 1992 Cadbury report. In 1996, the Dutch corporate governance code was released by the Peters Committee (de Jong et al., forthcoming). Regarding the supervisory board, the Dutch code recommendations address independence, conflicts of interest and multiple board memberships.

${ }^{16}$ Voogd (1989) documents that in 1988, 51\% of the Dutch listed companies examined had "defensive" preferred shares, $44 \%$ was under the structured regime, $32 \%$ had certificates and $49 \%$ had binding nominations. De Jong and Röell (forthcoming) find that the priority shares are present in $28 \%$ of the firms 
in 1958 and 43\% in 1993. Priority shares are often found in family firms; in 1958 45\% of the family firms had priority shares, while only $22 \%$ of the other firms used this measure.

${ }^{17}$ Under Dutch law, preferred shares can be designed to provide a much larger ratio of voting power to paid-in capital than ordinary shares. The foundation can even be set up to be self-financing: it can borrow the amount required for the paid-in capital, receive dividends on the preferred shares that are tied to the required interest on the loan, and with cumulative preferred rights, the foundation can be assured of meeting its obligations (Voogd, 1989).

${ }^{18}$ Ahold used this takeover defense in 1989 to successfully fight off a takeover attempt by a German retailer, ASKO. In June 1989, SHV, a Dutch non-listed family firm that owns Makro, a major Dutch wholesale dealer, announced that it had been in talks with Ahold about co-operation for three years. From spring 1988 until May 5, 1989, SHV had accumulated a 12\% stake in Ahold with the objective of forcing Ahold to co-operation. When Ahold refused, SHV announced its plans to sell its Ahold shares (Het Financieele Dagblad, June 28, 1989). To the surprise of Ahold, ASKO announced its purchase of the 12\% stake from SHV plus another 3\% in August 1989, Table 10 (due to the reporting date, May of each year, blockholder stakes sometimes appear the following year). ASKO's objective was to force Ahold into cooperation as well. On August 29, 1989, the SAC of Ahold placed its preferred shares in order to deter ASKO and keep control of Ahold; Ahold's share price dropped 7.7\% ( $t$-statistic=-7.7).

${ }^{19}$ It is instructive to detail how management controlled the SAC. From 1986 to 1992, two of the five members of this foundation were supervisory board members. Beginning in 1993, the chairmen of the management (van der Hoeven) and supervisory board (Choufoer) were non-voting members of the foundation board. The three other members, de Soet, Hooglandt and Knuls, had voting rights. It is striking that de Soet who had been a member of the supervisory board since 1983 was now an advisor to the supervisory board with full voting privileges on the supervisory board. In 1996, de Ruiter replaced Choufoer, both as chair of the supervisory board and member of the foundation's board. In 1997 and 1998, van Dun replaced de Soet (van Dun retired in 1997 from the supervisory board after 24 years with Ahold) and Hooglandt was replaced by Slechte (former president of Shell Nederland with past positions with institutional investor Fortis). In 2000, de Vin replaces Knulst; de Vin was a retired partner at De Brauw Blackstone Westbroek, Ahold's attorney. The objective of the SAC was to maintain management control in case of a takeover threat. Ahold's management accomplished their objective. This is not in line with the listing requirements of the Amsterdam Stock Exchange, which require since 1989 that the members of trust offices such as SAC be independent of firm's boards.

${ }^{20}$ With the inception of the European Union in 1992, an overriding concern in 1989 was competition policy and the integration of EU markets. The European retail grocery industry was anxious about the threat of further consolidation in the manufacturing portion of the food industry and its adverse consequences for the retail chains and independent stores. Co-operative arrangements across countries were a potential way of mitigating this threat. In 1989, Ahold formed an alliance with Argyll (UK) and Casino (France) called the ERA or the European Retail Alliance. In order to strengthen the ties among the three companies, Argyll and Casino each bought $4 \%$ of Ahold's shares, see Table 10. Due to the reporting date (May of each year), Argyll's and Casino's stakes are first reported in 1990. Ahold bought about 1.5\% of Argyll's shares and $3.4 \%$ of Casino's.

${ }^{21}$ The stakes in Table 10 are the sum of ordinary shares and the certificates of preferred shares. Dutch ownership notification regulation does not allow a differentiation between classes of shares.

${ }^{22}$ In annual reports, no information is disclosed about the board of the SAPFA. In 1997, Dutch Chamber of Commerce filings indicate that the board consisted of Choufoer (former supervisory board Ahold), Bergsma (former AKZO), Heida (investment manager at ING) and Schaafsma (De Brauw Blackstone Westbroek, Ahold's attorneys) and Cram. In the 2001 shareholders meeting, Brüggeman was appointed and shareholders asked him to step forward. He was not present and no vita was available. In response to an individual request, Ahold provided the members per April 18, 2002: Bergsma, Schaafsma, Bouma (finance professor, supervisory board SNS Reaal, Dutch bank-insurer, and member of board of a foundation holding shares of Aegon), Izerda and Brüggeman.

${ }^{23}$ Firms with more than half of the workforce outside the Netherlands are not required to adopt the structured regime. Thus, Ahold had the right to abolish the regime already in the mid-1990s. It was a custom among Dutch multinationals to keep the regime on a voluntary basis even if they were no longer legally required to adopt it. 
${ }^{24}$ Ab Heijn was very distant supervisor. In his memoirs (de Jager, 1997, p.233), Ab mentions that in the early 1960s his uncle had been obstructing him from the supervisory board and he stated “.... I had decided not to interfere with my successors, as my Uncle did with me. .... Per January 1 1990, I entered the supervisory board but during the meetings I followed 'with finger tops against each other'." This expression means that he listened but he was not actively involved.

${ }^{25}$ Though Tobin owns no shares in Ahold, he had 278,000 options, which were awarded when Tobin was on the management board.

${ }^{26}$ According to Smit (2004, p.268), Schneider, an art professor and former US ambassador to The Netherlands, was given an internal introduction into US and Dutch GAAP and mentions not to have understood the issue. In a radio interview shortly after the events in February 2003, she states "I don't feel responsible. I am not a business person.” (Intermediair, June 12, 2003)

${ }^{27}$ Both in 1998 and 2001 Elan, a Dutch magazine for board members, announced that on the basis of board positions, de Ruiter was the most powerful supervisory board person in the Netherlands. Ferris, Jagannathan and Pritchard. (2003) find that in 1995 3,190 US firms with assets over \$100 million have 23,673 directors. Less than $0.5 \%$ of these directors have more than four positions. The authors find no relation between multiple directorships and firm performance.

${ }^{28}$ The only additional information from the 20-F's was the remuneration committee members for 2001, $\mathrm{H}$. de Ruiter, R.J. Nelissen, and M. Perry. De Ruiter and Nelissen were chair and vice-chair of the supervisory board and Nelissen has been discussed.

${ }^{29}$ For example, when Ab Heijn retired in 1997 "the supervisory board asks the management board to think about the nomination of new members. This is the habit in Ahold. The management board determines the composition of the supervisory board, because normally their nominations are followed" (Smit, 2004, p.175). Other examples illustrating this relationship are de Ruiter's argument with van der Hoeven about the takeover in Brazil. In the end, de Ruiter agreed (Smit, 2004, p.165). De Ruiter argued with van der Hoeven about the 15\% growth promised. Van der Hoeven replied: "I promised it and did it" (Smit, 2004, p.195).

${ }^{30}$ Net proceeds from the option exercises are based on the options exercised by all employees (not only board members). The ratio is therefore only an approximation of the ratio between the net proceeds board members received from exercising their options and their cash compensation.

${ }^{31}$ The formula for the annual ratio is [(average monthly stock price minus average price of options exercised) times (number of options exercised)] divided by [management board compensation]. Also recall that there are 150 members of the firm under the option plan from 1987 to 1997.

${ }^{32}$ The academic literature argues that dividends and leverage are corporate governance mechanisms (e.g., Jensen, 1986, Easterbrook, 1984). Ahold's management successfully circumvented the potential role of dividends on ordinary shares as a disciplining device. Until 1989, Ahold paid cash dividends. Beginning in 1989, it initiated a choice dividend (e.g., in 1989, investors received an interim dividend of fl $0.50+\$ 0.05$ and a year end choice dividend of fl $1.10+\$ 0.20$ or $2 \%$ in shares). The ratio of shares to cash could be set such that shareholders chose the stock dividend (of course, tax issues are important here). Beginning in 1990, interim dividends were also choice dividends. Choice dividends allowed management to influence the cash outflow, without announcing a dividend reduction. If van der Hoeven wanted to keep cash he could make stock attractive; if he wanted fewer shares; he could favor cash dividends. The debt levels and the interest coverage ratio in Table 3 show that until 2002 the coverage was always well above twice the interest payments, while debt levels were relatively high in 2000.

${ }^{33}$ Van der Hoeven stepped down at the end of 2002 (Het Financieele Dagblad, December 21, 2002) in order to fully concentrate on Ahold.

${ }^{34}$ SDC New Issues Database contains data on gross spreads for 28 out of Ahold's 46 debt and equity issues. A total of $\$ 384.2$ million was paid out in the 16 debt and equity issues lead managed by ABN-Amro It is plausible to assume that $\mathrm{ABN}$-Amro earned a significant part of these gross spreads. 
Table 1: Geographical distribution of Ahold's sales and operating profit

\begin{tabular}{|c|c|c|c|c|c|c|c|c|c|c|c|c|}
\hline Year & $\begin{array}{l}\text { Total sales } \\
\text { (€ million) }\end{array}$ & Netherlands & Europe & "US & $\begin{array}{c}\text { Latin } \\
\text { America }\end{array}$ & Asia & $\begin{array}{c}\text { Operating } \\
\text { profit (€ } \\
\text { million) }\end{array}$ & $\begin{array}{l}\text { Netherlands } \\
\text { (€ million) }\end{array}$ & $\begin{array}{l}\text { Europe } \\
\quad(€ \\
\text { million) }\end{array}$ & $\begin{array}{c}\text { US (€ } \\
\text { million) }\end{array}$ & $\begin{array}{c}\text { Latin } \\
\text { America } \\
(€ \\
\text { million) }\end{array}$ & $\begin{array}{c}\text { Asia } \\
(€ \\
\text { million) }\end{array}$ \\
\hline 1976 & $1,539.7$ & $100.0 \%$ & $0.0 \%$ & $0.0 \%$ & $0.0 \%$ & $0.0 \%$ & NA & NA & NA & NA & NA & NA \\
\hline 1980 & $2,641.5$ & $76.6 \%$ & $0.9 \%$ & $22.5 \%$ & $0.0 \%$ & $0.0 \%$ & NA & NA & NA & NA & NA & NA \\
\hline 1984 & $4,811.0$ & $55.1 \%$ & $1.3 \%$ & $43.6 \%$ & $0.0 \%$ & $0.0 \%$ & NA & NA & NA & NA & NA & NA \\
\hline 1989 & $7,747.8$ & $49.6 \%$ & $0.0 \%$ & $50.4 \%$ & $0.0 \%$ & $0.0 \%$ & NA & NA & NA & NA & NA & NA \\
\hline 1990 & $7,678.0$ & $52.5 \%$ & $0.0 \%$ & $47.5 \%$ & $0.0 \%$ & $0.0 \%$ & NA & NA & NA & NA & NA & NA \\
\hline 1991 & $9,130.5$ & $47.4 \%$ & $0.3 \%$ & $52.3 \%$ & $0.0 \%$ & $0.0 \%$ & NA & NA & NA & NA & NA & NA \\
\hline 1992 & $9,798.9$ & $47.6 \%$ & $1.0 \%$ & $51.5 \%$ & $0.0 \%$ & $0.0 \%$ & NA & NA & NA & NA & NA & NA \\
\hline 1993 & $12,293.8$ & $49.5 \%$ & $5.0 \%$ & $45.4 \%$ & $0.0 \%$ & $0.0 \%$ & 320.7 & 156.9 & 27.1 & 136.7 & 0.0 & 0.0 \\
\hline 1994 & $13,149.2$ & $48.3 \%$ & $5.2 \%$ & $46.5 \%$ & $0.0 \%$ & $0.0 \%$ & 365.6 & 170.4 & 40.7 & 154.5 & 0.0 & 0.0 \\
\hline 1995 & $13,439.6$ & $48.4 \%$ & $6.4 \%$ & $45.2 \%$ & $0.0 \%$ & $0.0 \%$ & 439.3 & 222.2 & 55.6 & 161.5 & 0.0 & 0.0 \\
\hline 1996 & $16,580.2$ & $41.0 \%$ & $7.0 \%$ & $52.0 \%$ & $0.0 \%$ & $0.2 \%$ & 589.7 & 251.9 & 75.1 & 272.1 & 0.0 & -9.3 \\
\hline 1997 & $22,946.8$ & $31.5 \%$ & $6.3 \%$ & $55.2 \%$ & $5.2 \%$ & $1.8 \%$ & 865.9 & 275.4 & 81.2 & 508.4 & 36.5 & -35.6 \\
\hline 1998 & $26,484.0$ & $29.1 \%$ & $6.6 \%$ & $54.8 \%$ & $8.0 \%$ & $1.6 \%$ & $1,057.2$ & 304.6 & 97.6 & 639.0 & 62.8 & -46.9 \\
\hline 1999 & $33,560.0$ & $31.2 \%$ & NA & $57.0 \%$ & $10.4 \%$ & $1.4 \%$ & $1,458.8$ & 459.0 & NA & 943.8 & 96.7 & -40.8 \\
\hline 2000 & $52,468.0$ & $31.7 \%$ & NA & $57.9 \%$ & $9.7 \%$ & $0.8 \%$ & $2,320.2$ & 669.9 & NA & $1,466.0$ & 204.1 & -19.8 \\
\hline 2001 & $66,591.0$ & $32.8 \%$ & NA & $59.3 \%$ & $7.4 \%$ & $0.6 \%$ & $2,760.8$ & 865.6 & NA & $1,713.0$ & 200.1 & -18.0 \\
\hline 2002 & $62,635.0$ & $21.9 \%$ & NA & $74.0 \%$ & $3.4 \%$ & $0.7 \%$ & 606.0 & -646.0 & NA & $1,563.0$ & -33.0 & -278.0 \\
\hline 2003 & $63,614.0$ & $33.6 \%$ & NA & $62.3 \%$ & $3.5 \%$ & $0.6 \%$ & 912.0 & 194.0 & NA & 946.0 & -166.0 & -62.0 \\
\hline
\end{tabular}

Note: Table shows the geographical distribution of Ahold's sales and operating profit during 1976-2003. Data is taken from the annual reports and 20-F forms. Operating profit is taken from form 20-F and is based on US GAAP. The sales in the Netherlands, European countries (other than the Netherlands), the US, Latin America and Asia are expressed as a percentage of total sales/operating profit. In 1999, the annual report no longer distinguishes between the sales in the Netherlands and other European countries. The number reported under the Netherlands from 1999 relates to the Netherlands and other European countries and is not strictly comparable with the numbers for the preceding years. NA denotes not available. The numbers for 2000 and 2001 are before the restatement Ahold published in 2002. 
Table 2: Financial information of Ahold

\begin{tabular}{|c|c|c|c|c|c|c|}
\hline Year & $\begin{array}{l}\text { Total assets } \\
\text { (€ million) }\end{array}$ & $\begin{array}{l}\text { Debt-to- } \\
\text { equity } \\
\text { ratio }\end{array}$ & $\begin{array}{c}\text { Interest } \\
\text { coverage } \\
\text { ratio }\end{array}$ & $\begin{array}{l}\text { Operating } \\
\text { cash flow ( } € \\
\text { thousands) }\end{array}$ & $\begin{array}{l}\text { Net income } \\
\text { ( } € \\
\text { thousands) }\end{array}$ & $\begin{array}{l}\text { Earnings } \\
\text { per share } \\
(€)\end{array}$ \\
\hline 1976 & $356,121.7$ & 1.88 & 3.80 & NA & $12,962.2$ & 0.13 \\
\hline 1980 & $567,239.3$ & 2.05 & 5.25 & NA & $23,534.4$ & 0.18 \\
\hline 1984 & $1,293,441.1$ & 1.93 & 2.82 & NA & $49,243.8$ & 0.25 \\
\hline 1989 & 1,925,612.3 & 1.70 & 2.70 & $232,887.7$ & $88,304.3$ & 0.32 \\
\hline 1990 & $1,939,454.8$ & 1.67 & 4.10 & $302,804.4$ & $110,408.8$ & 0.38 \\
\hline 1991 & $2,439,055.0$ & 2.83 & 3.00 & $349,182.1$ & $125,159.4$ & 0.42 \\
\hline 1992 & 2,873,652.6 & 3.00 & 2.90 & $343,592.9$ & $138,422.0$ & 0.45 \\
\hline 1993 & 3,623,135.1 & 2.39 & 2.49 & 307,956.6 & $155,698.3$ & 0.45 \\
\hline 1994 & 3,705,389.5 & 2.30 & 2.92 & $462,267.3$ & $185,841.6$ & 0.52 \\
\hline 1995 & $4,195,437.7$ & 2.63 & 3.12 & $693,630.3$ & $207,187.4$ & 0.57 \\
\hline 1996 & .8 & 3.79 & 3.32 & 522 , & 286 & 0.65 \\
\hline 1997 & .9 & 3.64 & 3.04 & $924,692.0$ & 423 & 0.80 \\
\hline 1998 & $11,426,373.3$ & 4.75 & 3.18 & 1,257,694.1 & $547,198.6$ & 0.93 \\
\hline 1999 & $14,285,642.0$ & 5.17 & 3.36 & 2,699,879.0 & $752,107.0$ & 1.15 \\
\hline 2000 & $25,460,624.0$ & 6.45 & 2.80 & $2,600,734.0$ & $1,115,991.0$ & 1.51 \\
\hline 2001 & $32,236,464.0$ & 3.59 & 2.65 & $2,375,721.0$ & $1,113,521.0$ & $1.73^{\#}$ \\
\hline 2002 & $24,738,000.0$ & 7.47 & 0.24 & $2,486,000.0$ & $-1,246,000.0$ & $-0.85^{\#}$ \\
\hline 2003 & $23,399,000.0$ & 3.31 & 0.70 & $1,909,000.0$ & $-39,000.0$ & $-0.04^{*}$ \\
\hline
\end{tabular}

Note: Table shows financial information of Ahold during 1976-2003. Data is taken from the annual reports and is based on Dutch GAAP. Sales margin is computed as Earnings before Interest and Taxes (EBIT) divided by sales. The debt-to-equity ratio is calculated as the ratio of short-term and long-term debt and the book value of equity. The interest coverage ratio is defined as the ratio of EBIT and interest paid. Earnings per share is the number reported in the annual report adjusted for stock splits. " The data for 2000 and 2001 are from the annual accounts as originally published (i.e., before the restatement of the accounts in 2002). In 2001 and 2002 Ahold reports earnings per share before goodwill amortization and extraordinary items. The earnings per share after goodwill amortization and extraordinary items equals €1.25 per share in 2001 and $-€ 1.34$ per share in $2002{ }^{*}$ In 2003 Ahold reports earnings per share after dividends on cumulative preferred shares. Before these dividends the earnings per share equals $€ 0$. NA denotes not available. 
Table 3: Ahold's major acquisitions during 1989-2003

\begin{tabular}{|c|c|c|c|c|c|}
\hline $\begin{array}{l}\text { Announcement } \\
\text { date }\end{array}$ & $\begin{array}{l}\text { Name of target } \\
\text { company }\end{array}$ & Country & $\begin{array}{l}\% \\
\text { acquisition }\end{array}$ & $\begin{array}{l}\text { Deal value } \\
(€ \text { million) }\end{array}$ & $\begin{array}{l}\text { Announce } \\
\text { ment } \\
\text { return }\end{array}$ \\
\hline 28-2-1991 & Tops Markets & US & $100 \%$ & $€ 332.67$ & $\begin{array}{l}3.29 \% \\
(3.91)\end{array}$ \\
\hline 22-2-1994 & Red Food Stores & US & $100 \%$ & $€ 116.08$ & $\begin{array}{l}0.32 \% \\
(0.28)\end{array}$ \\
\hline 29-3-1996 & Stop \& Shop & US & $100 \%$ & $€ 2,307.82$ & $\begin{array}{l}2.56 \% \\
(2.49)\end{array}$ \\
\hline $15-11-1996$ & $\begin{array}{l}\text { Supermercados } \\
\text { Bompreço }\end{array}$ & Brazil & $50 \%$ & $€ 215.55$ & $\begin{array}{l}-0.68 \% \\
(-0.68)\end{array}$ \\
\hline $15-1-1998$ & $\begin{array}{l}\text { Disco (joint venture } \\
\text { with Velox Retail } \\
\text { Holdings) }\end{array}$ & Argentina & $50 \%$ & $€ 339.64$ & $\begin{array}{l}1.19 \% \\
(0.85)\end{array}$ \\
\hline 20-5-1998 & Giant Food & US & $100 \%$ & $€ 2,436.62$ & $\begin{array}{l}1.90 \% \\
(1.58)\end{array}$ \\
\hline 18-12-1998 & $\begin{array}{l}\text { Disco (joint venture } \\
\text { with Velox Retail } \\
\text { Holdings) }\end{array}$ & Argentina & $34 \%$ & $€ 506.71$ & $\begin{array}{l}-1.60 \% \\
(-0.85)\end{array}$ \\
\hline 10-12-1999 & $\begin{array}{l}\text { ICA (joint venture } \\
\text { with ICA } \\
\text { Förbundet/Canica) }\end{array}$ & $\begin{array}{l}\text { Norway/ } \\
\text { Sweden }\end{array}$ & $50 \%$ & $€ 1,800.00$ & $\begin{array}{l}-3.47 \% \\
(-2.36)\end{array}$ \\
\hline $8-3-2000$ & US Food Service & US & $100 \%$ & $€ 3,776.04$ & $\begin{array}{l}-3.08 \% \\
(-1.32)\end{array}$ \\
\hline $23-5-2000$ & $\begin{array}{l}\text { Supermercados } \\
\text { Bompreço }\end{array}$ & Brazil & $50 \%$ & $€ 240.18$ & $\begin{array}{l}-0.41 \% \\
(-0.16)\end{array}$ \\
\hline $8-9-2000$ & Superdiplo & Spain & $97.64 \%$ & $€ 1,250.00$ & $\begin{array}{l}-7.11 \% \\
(-4.00)\end{array}$ \\
\hline $6-12-2000$ & PYA/Monarch & US & $100 \%$ & $€ 1,843.49$ & $\begin{array}{l}-4.50 \% \\
(-3.09)\end{array}$ \\
\hline $30-11-2001$ & Alliant Exchange & US & $100 \%$ & $€ 2,467.52$ & $\begin{array}{l}-0.22 \% \\
(-0.17)\end{array}$ \\
\hline $12-12-2001$ & $\begin{array}{l}\text { Bruno's } \\
\text { Supermarkets }\end{array}$ & US & $100 \%$ & $€ 556.90$ & $\begin{array}{l}-2.50 \% \\
(-1.82) \\
\end{array}$ \\
\hline
\end{tabular}

Note: Table shows Ahold's completed acquisitions with a deal value exceeding $€ 100$ million during 19892003. Dollar amounts have been converted into euros using the dollar/euro or dollar/ecu exchange rate where appropriate. Data is collected from annual reports, newspapers and the ZEPHYR, SDC Mergers \& Acquisitions databases. Announcement returns are the cumulative abnormal returns for the announcement day (day 0) and the day before (day -1). Abnormal returns are based on the market model (100 day estimation period from - 110 to -10 days before announcement day). $T$-statistics are calculated by dividing the cumulative abnormal returns from day -1 to day 0 by the standard deviation of the abnormal returns during the estimation period. $T$-statistics are in parentheses. 


\section{Table 4: Foreign markets}

\begin{tabular}{lll}
\hline \hline $\begin{array}{l}\text { Year of } \\
\text { first entry }\end{array}$ & Country & Entry mode \\
\hline 1976 & Spain & Opening supermarkets \\
1977 & United States & Acquisition of BI-LO (100\%) \\
1988 & Belgium & Opening drugstores \\
1991 & Czech Republic & Joint venture with Pramen Ostrava \\
1992 & Portugal & Joint venture with Jerónimo Martins (49\%) \\
1995 & Poland & Joint venture with Allkauf (50\%) \\
1996 & Brazil & Acquisition of Supermercados Bompreço (50\%) \\
1996 & China & Joint venture with China Venturetech Investment Corp. \\
& & (50\%) \\
1996 & Malaysia, Singapore & Joint venture with Kuok Group (60\%) \\
1997 & Thailand & Joint venture with Central Robinson Group (49\%) \\
1997 & Indonesia & Acquisition of PT Putra Serasi Pioneerindo (70\%) \\
1998 & Argentina, Chile, Equador, & Joint venture with Velox Retail Holdings (50\%) \\
& Paraguay, Peru & \\
1999 & El Salvador, Guatemala, & Joint venture with La Fragua (50\%) \\
& Honduras & \\
1999 & Estonia, Latvia, Lithuania, & Joint venture with Canica and ICA Förbundet (50\%) \\
& Norway, Sweden & \\
2001 & Denmark & Joint venture with Dansk Supermarked (50\%) \\
2001 & Slovak Republic & Opening supermarkets \\
\hline \hline
\end{tabular}

Note: Table shows Ahold's year of first entry into a foreign market as well as the entry mode. Data is collected from annual reports and newspapers. 
Table 5: Ahold's major equity and debt offerings during 1989-2003

\begin{tabular}{|c|c|c|c|c|c|}
\hline $\begin{array}{l}\text { Issue date } \\
\text {. }\end{array}$ & $\begin{array}{l}\text { Proceeds } \\
\text { (million) }\end{array}$ & Details & "Bookrunner(s) & Motive & $\begin{array}{l}\text { Announce } \\
\text { ment } \\
\text { return } \\
\end{array}$ \\
\hline $15-7-1996$ & $€ 1,575.29$ & $\begin{array}{l}\text { Public of offering of } 36 \\
\text { million shares }\end{array}$ & Goldman Sachs & $\begin{array}{l}\text { Financing } \\
\text { acquisition of Stop } \\
\text { \& Shop }\end{array}$ & $\begin{array}{l}9.23 \% \\
(9.03)\end{array}$ \\
\hline $1-4-1998$ & $€ 662.14$ & $\begin{array}{l}\text { Public of offering of } 30 \\
\text { million shares }\end{array}$ & $\begin{array}{l}\text { ABN- } \\
\text { Amro/Goldman } \\
\text { Sachs }\end{array}$ & $\begin{array}{l}\text { Financing } \\
\text { acquisition of Disco } \\
\text { and other smaller } \\
\text { acquisitions }\end{array}$ & $\begin{array}{l}1.35 \% \\
(1.09)\end{array}$ \\
\hline 24-9-1998 & $€ 790.71$ & $\begin{array}{l}\text { Public offering of } 45 \\
\text { million shares }\end{array}$ & $\begin{array}{l}\text { ABN- } \\
\text { Amro/Goldman } \\
\text { Sachs }\end{array}$ & $\begin{array}{l}\text { Financing } \\
\text { acquisition of Giant }\end{array}$ & $\begin{array}{l}-5.02 \% \\
(-3.78)\end{array}$ \\
\hline 25-9-1998 & $€ 879.11$ & $\begin{array}{l}\text { 3\% convertible bonds } \\
\text { and American depository } \\
\text { notes due } 2003\end{array}$ & $\begin{array}{l}\text { ABN- } \\
\text { Amro/Goldman } \\
\text { Sachs }\end{array}$ & $\begin{array}{l}\text { Financing } \\
\text { acquisition of Giant }\end{array}$ & $\begin{array}{l}-5.02 \% \\
(-3.78)\end{array}$ \\
\hline 23-4-1999 & $€ 932.19$ & $\begin{array}{l}6.875 \% \text { guarantee notes } \\
\text { due } 2029 \text { and } 6.25 \% \\
\text { guarantee notes due } \\
2009\end{array}$ & $\begin{array}{l}\text { Chase } \\
\text { Securities/JP } \\
\text { Morgan }\end{array}$ & $\begin{array}{l}\text { General corporate } \\
\text { purposes }\end{array}$ & $\begin{array}{l}1.89 \% \\
(1.21)\end{array}$ \\
\hline $15-5-2000$ & $€ 2,397.52$ & $\begin{array}{l}\text { Public offering of } 93 \\
\text { million shares }\end{array}$ & $\begin{array}{l}\text { ABN- } \\
\text { Amro/Goldman } \\
\text { Sachs/Merrill } \\
\text { Lynch }\end{array}$ & $\begin{array}{l}\text { Financing } \\
\text { acquisition of its } \\
50 \% \text { stake in ICA } \\
\text { and US Food } \\
\text { Service }\end{array}$ & $\begin{array}{l}-3.08 \% \\
(-1.32)\end{array}$ \\
\hline $16-5-2000$ & $€ 791.81$ & $\begin{array}{l}\text { 4\% subordinated } \\
\text { convertible bonds due } \\
2005\end{array}$ & $\begin{array}{l}\text { ABN- } \\
\text { Amro/Goldman } \\
\text { Sachs/Merrill } \\
\text { Lynch }\end{array}$ & $\begin{array}{l}\text { Financing } \\
\text { acquisition of its } \\
50 \% \text { stake in ICA } \\
\text { and US Food } \\
\text { Service }\end{array}$ & $\begin{array}{l}-3.08 \% \\
(-1.32)\end{array}$ \\
\hline $25-5-2000$ & $€ 1,507.44$ & $\begin{array}{l}6.375 \% \text { fixed straight } \\
\text { bond due } 2005 \text { under } \\
\text { Euro Medium Term } \\
\text { Note Program }\end{array}$ & $\begin{array}{l}\text { ABN-Amro/Chase } \\
\text { Manhattan }\end{array}$ & $\begin{array}{l}\text { Refinancing } \\
\text { acquisition of US } \\
\text { Food Service and its } \\
50 \% \text { stake in ICA }\end{array}$ & $\begin{array}{l}5.29 \% \\
(1.98)\end{array}$ \\
\hline $17-7-2000$ & $€ 745.77$ & $8.25 \%$ notes due 2010 & JP Morgan & $\begin{array}{l}\text { Refinancing existing } \\
\text { debt of US Food } \\
\text { Service }\end{array}$ & $\begin{array}{l}2.14 \% \\
(0.90)\end{array}$ \\
\hline $\begin{array}{l}22-10- \\
2000\end{array}$ & $€ 403.00$ & $\begin{array}{l}\text { Private offering of } \\
\text { 115,317,164 cumulative } \\
\text { preferred shares }\end{array}$ & Kempen \& Co. & $\begin{array}{l}\text { Financing Dutch } \\
\text { operations }\end{array}$ & $\begin{array}{l}-0.07 \% \\
(-0.04)\end{array}$ \\
\hline $26-4-2001$ & $€ 1,192.99$ & $\begin{array}{l}5.875 \% \text { notes due } 2008 \\
\text { under Euro Medium } \\
\text { Term Note Program }\end{array}$ & Goldman Sachs & $\begin{array}{l}\text { General corporate } \\
\text { purposes }\end{array}$ & $\begin{array}{l}-0.56 \% \\
(-0.39)\end{array}$ \\
\hline 5-9-2001 & $€ 2,226.63$ & $\begin{array}{l}\text { Public offering of } 70 \\
\text { million shares } \\
\text { (accelerated offering) }\end{array}$ & $\begin{array}{l}\text { ABN- } \\
\text { Amro/Goldman } \\
\text { Sachs/Merrill } \\
\text { Lynch }\end{array}$ & $\begin{array}{l}\text { Financing } \\
\text { acquisitions of } \\
\text { Alliant Foodservices } \\
\text { and Bruno’s } \\
\text { Supermarkets }\end{array}$ & $\begin{array}{l}-2.06 \% \\
(-2.58)\end{array}$ \\
\hline
\end{tabular}




\section{Table 5: Ahold's major equity and debt offerings during 1989-2003 (continued)}

\begin{tabular}{|c|c|c|c|c|c|}
\hline Issue date & $\begin{array}{l}\text { Proceeds } \\
\text { (million) }\end{array}$ & Details & "Bookrunner(s) & Motive & $\begin{array}{l}\text { Announce } \\
\text { ment } \\
\text { return }\end{array}$ \\
\hline 6-12-2001 & $€ 1,400.91$ & $\begin{array}{l}\text { 5.875\% fixed straight } \\
\text { bond due } 2012 \text { and } 6.5 \% \\
\text { fixed straight bond due } \\
2017\end{array}$ & $\begin{array}{l}\text { JP } \\
\text { Morgan/Morgan } \\
\text { Stanley }\end{array}$ & $\begin{array}{l}\text { Refinancing short- } \\
\text { term debts }\end{array}$ & $\begin{array}{l}0.99 \% \\
(0.75)\end{array}$ \\
\hline $\begin{array}{l}11-12- \\
2003\end{array}$ & $€ 2,967.00$ & $\begin{array}{l}\text { Rights issue of } 621 \\
\text { million shares }\end{array}$ & $\begin{array}{l}\text { ABN- } \\
\text { Amro/Goldman } \\
\text { Sachs/JP } \\
\text { Morgan/Rabobank }\end{array}$ & $\begin{array}{l}\text { To reduce debt } \\
\text { burden of } € 11 \\
\text { billion }\end{array}$ & $\begin{array}{l}3.23 \% \\
(1.22)\end{array}$ \\
\hline
\end{tabular}

Note: Table shows all major debt and equity offerings with proceeds exceeding $€ 500$ million. Debt and equity offerings are identified through the SDC New Issues database and a Lexis Nexis search. Motives are from newspapers and press releases. Announcement dates are from Dow Jones Newswires and Reuters. Announcement returns are the cumulative abnormal returns for the announcement day (day 0) and the day before (day -1). Abnormal returns are based on the market model (100 day estimation period from -110 to 10 days before announcement day). $T$-statistics are calculated by dividing the cumulative abnormal returns from day -1 to day 0 by the standard deviation of the abnormal returns during the estimation period. $T$ statistics are in parentheses. 
Table 6: Reconciliation of Dutch and US GAAP net earnings

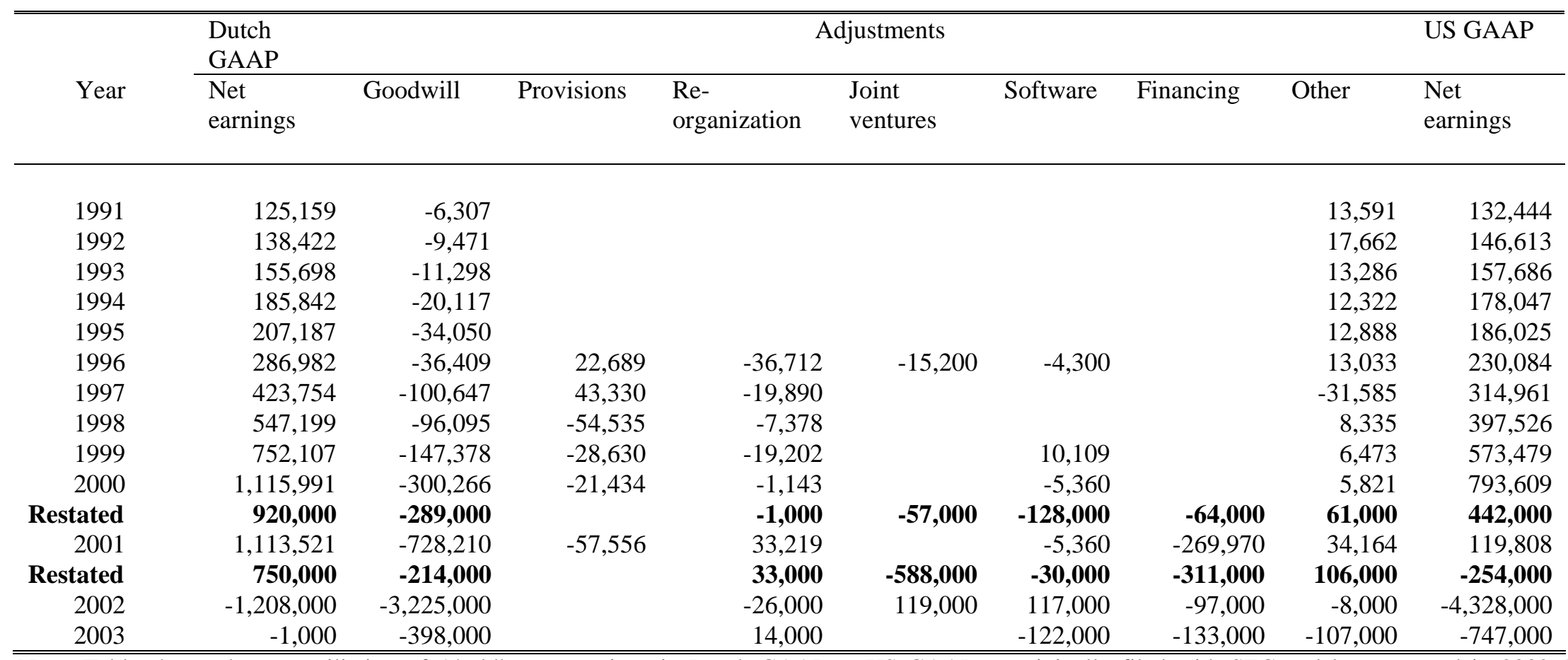

Note: Table shows the reconciliation of Ahold's net earnings in Dutch GAAP to US GAAP as originally filed with SEC and later restated in 2002 (in $€$ thousands). Data is collected from 20-F forms filed with SEC. Goodwill: Under Dutch GAAP, goodwill is charged directly to the acquiring firm's shareholders' equity and this treatment is reflected in the Dutch GAAP net earnings numbers. US GAAP required goodwill to be capitalized and amortized over a period not to exceed 40 years. In 2001, US GAAP changed, SFAS No. 142 (Goodwill and Other Intangibles); goodwill with a finite life is amortized over its useful life and goodwill with an infinite life is not amortized but is annually subjected to an impairment test. In 2002, this resulted in a charge of $€ 3.2$ billion, which included an impairment of $€ 1.85$ billion associated with US Food Service. Joint Ventures: This item reflects the accounting differences associated with joint ventures under Dutch GAAP and US GAAP. Up to 2000, Dutch GAAP did not recognize impairment losses and all goodwill relating to joint ventures is charged directly to shareholders' equity upon acquisition. After 2000, goodwill must be amortized over its useful life with a maximum of 20 years. For 2001 restated, €505 million of the $€ 588$ million is associated with the DISCO joint venture. The $€ 505$ million was reclassified from the goodwill adjustment in the original numbers to the joint venture adjustment in the restated numbers. Provisions, Reorganization and Software: provisions, allowances and reserves adjustments, reorganization cost adjustments and software cost adjustments reflecting the differences between Dutch and US GAAP. Financing: Differences between Dutch and US GAAP concerning, sale and leaseback, derivatives, and options transactions. Restated: Restatements of 2000 and 2001 due to fraud, errors and omissions discovered in 2002 are printed in bold. Also see Table 9. 
Table 7: Accounting fraud: Dutch GAAP restatements in 2000 and 2001

\begin{tabular}{|c|c|c|}
\hline & 2000 & 2001 \\
\hline $\begin{array}{l}\text { Net Income under Dutch GAAP as } \\
\text { previously reported }\end{array}$ & $1,116,000$ & $1,113,000$ \\
\hline \multicolumn{3}{|l|}{ Correction of errors } \\
\hline Deconsolidation & 0 & 0 \\
\hline Deconsolidation Adjustments & $-10,000$ & $-5,000$ \\
\hline Vendor Allowances ${ }^{1}$ & $-103,000$ & $-215,000$ \\
\hline Acquisition Adjustments & $-8,000$ & $-36,000$ \\
\hline Provisions & $-38,000$ & $-33,000$ \\
\hline Real Estate Transactions & $-26,000$ & $-2,000$ \\
\hline Other & $-21,000$ & $-53,000$ \\
\hline \multicolumn{3}{|l|}{ Changes in accounting principles } \\
\hline Pensions & 11,000 & 16,000 \\
\hline Revaluations & $-1,000$ & $-4,000$ \\
\hline Restructuring Provisions & & $-35,000$ \\
\hline $\begin{array}{l}\text { Net Income under Dutch GAAP as } \\
\text { restated }\end{array}$ & 920,000 & 750,000 \\
\hline $\begin{array}{l}\text { Note: Table shows the restatements } \\
\text { as later restated in } 2002 \text { (in } € \text { thous } \\
\text { discrepancy for vendor allowances }\end{array}$ & at income & $\begin{array}{l}\text { SEC and } \\
\text { The total } \\
\text { is number }\end{array}$ \\
\hline
\end{tabular}




\section{Table 8: OECD principles of corporate governance}

Corporate governance should protect shareholder rights

Basic shareholder rights include the right to elect members of the board

Shareholders have the right to participate in decisions concerning fundamental corporate change

(amendments to governance, authorization of shares, sale of the company)

Shareholders vote in general shareholder meetings (whether this is in person or in absentia)

Capital structures and arrangements that give certain shareholders a disproportionate degree of control should be disclosed

Market for corporate control should be allowed to function without anti-takeover devices

Shareholders, including institutional investors, should consider the costs and benefits of their votes

Corporate governance should ensure equitable protection of all shareholders, including minority and foreign shareholders

Corporate governance should recognize the rights of stakeholders as established by law and encourage the active co-operation between the corporation and stakeholders

Corporate governance should ensure that timely and accurate disclosure is made on all matters regarding the corporation (including financial, performance, ownership and governance)

Corporate governance should ensure the strategic guidance of the company, the effective monitoring of the management by the board, and the board's accountability to the company and shareholders

Board should act on a fully informed basis with due diligence and in the best interest of the company and shareholders

Board should treat all shareholders equally

Board should ensure compliance with the law

Board should fulfill certain key functions, including

- Reviewing and guiding corporate strategy; setting performance standards; monitoring implementation and corporate performance; overseeing major capital expenditures, acquisitions and divestures

- $\quad$ Selecting, compensating, monitoring and when necessary, replacing key executives and overseeing succession plans

- Reviewing key executive and board remuneration, and ensuring a formal and transparent board nomination process

- Monitoring and managing potential conflicts of interest of management, board members and shareholders

- Ensuring the integrity of the corporation's accounting and financial reporting systems

- Monitoring the effectiveness of its corporate governance practices

- Overseeing the process of disclosure and communication

Board should exercise objective judgment on corporate affairs independent, in particular, from management

- Board should consider assigning non-executive members to tasks where there is the potential for conflict of interest

- Board should devote sufficient time to their responsibilities

Board should have access to accurate, relevant and timely information

Note: Table summarizes the Organization for Economic Co-operation and Development's (OECD) Principles of Corporate Governance authored by the Ad Hoc Task Force on Corporate Governance in 1999. 
Table 9: Takeover defenses and shareholder rights at Ahold

\begin{tabular}{|c|c|c|}
\hline Takeover defense & Years & Description \\
\hline $\begin{array}{l}\text { Founder or priority } \\
\text { shares }\end{array}$ & $\begin{array}{l}1948- \\
1979\end{array}$ & $\begin{array}{l}\text { The founder shares entitled the Heijn family to make binding } \\
\text { nominations for all the members on the management board and } \\
\text { one member on the supervisory board. The founder shares also } \\
\text { entitled them to a part of the excess profit. In } 1979 \text { the founder } \\
\text { shares were stripped of their right to make binding nominations } \\
\text { for board positions }\end{array}$ \\
\hline Structured regime & $\begin{array}{l}1972- \\
2001\end{array}$ & $\begin{array}{l}\text { The structured regime is a legal requirement for large Dutch } \\
\text { companies. The regime transfers several decision rights from the } \\
\text { shareholders to the supervisory board such as the right to appoint } \\
\text { and dismiss members of the management board, to adopt the } \\
\text { annual accounts and the election of the supervisory board itself, } \\
\text { called co-optation. Multinationals are exempt but allowed to } \\
\text { have the regime voluntarily. Ahold could therefore have left the } \\
\text { regime in the 1990s. In } 2001 \text { Ahold abolished the regime, but } \\
\text { introduced binding nominations in its corporate charter }\end{array}$ \\
\hline Preferred shares & 1973-now & $\begin{array}{l}\text { The foundation Stichting Ahold Continuïteit (SAC) owns an } \\
\text { option to call preferred shares with a nominal value that equals } \\
\text { the current capital. In case of a takeover threat the foundation } \\
\text { will exercise the option and place the preferred shares - of } \\
\text { which only } 25 \% \text { has to be paid - among friendly parties. This } \\
\text { will dilute the stake of a hostile bidder. }\end{array}$ \\
\hline $\begin{array}{l}\text { Certificates of } \\
\text { preferred shares }\end{array}$ & 1996-now & $\begin{array}{l}\text { Certificates of preferred shares have been stripped of their } \\
\text { voting rights with the voting rights under control of a second } \\
\text { Ahold-related foundation Stichting Administratiekantoor } \\
\text { Preferente Financieringsaandelen Ahold (SAPFA). This } \\
\text { foundation, friendly to incumbent management, casts the votes } \\
\text { on the certificates of preferred shares held by the institutional } \\
\text { investors at the general meeting of shareholders. }\end{array}$ \\
\hline Binding nominations & 2001-now & $\begin{array}{l}\text { Ahold introduced into its corporate charter a right for the } \\
\text { supervisory board to nominate all supervisory and managerial } \\
\text { board members. The nominations are binding, but can be } \\
\text { rejected with } 2 / 3 \text { majority representing at least half of the } \\
\text { capital. }\end{array}$ \\
\hline
\end{tabular}

Note: Table shows Ahold's takeover defenses. Data is collected from annual reports, newspapers and de Jager (1995, 1997). 
Table 10: Ownership structure of Ahold

\begin{tabular}{|c|c|c|c|c|c|c|c|c|c|c|c|c|c|c|c|c|}
\hline Shareholder & "Description & 1989 & 1990 & 1991 & 1992 & 1993 & 1994 & 1995 & 1996 & 1997 & 1998 & 1999 & 2000 & 2001 & 2002 & 2003 \\
\hline SHV & $\begin{array}{l}\text { Non-listed } \\
\text { family firm }\end{array}$ & $12 \%$ & & & & & & & & & & & & & & \\
\hline Heijn family & Family & $7.3 \%$ & $7.3 \%$ & $7.7 \%$ & $7.7 \%$ & & & & & & & & & & & \\
\hline ASKO & Retail firm & & $15 \%$ & & & & & & & & & & & & & \\
\hline Argyll & Retail firm & & $4 \%$ & $4 \%$ & $4 \%$ & $4 \%$ & $4 \%$ & $4 \%$ & & & & & & & & \\
\hline Casino & Retail firm & & $4 \%$ & $4 \%$ & $4 \%$ & $4 \%$ & $4 \%$ & $4 \%$ & & & & & & & & \\
\hline ABP & Pension fund & & & & & & & & $5.4 \%$ & $5.4 \%$ & $5.4 \%$ & & & & & \\
\hline AEGON & Insurer & & & & & & & & & $6.1 \%$ & $6.1 \%$ & $6.1 \%$ & $6.1 \%$ & $6.1 \%$ & $6.1 \%$ & $6.1 \%$ \\
\hline Achmea & Insurer & & & & & & & & & $7.2 \%$ & $7.2 \%$ & $7.2 \%$ & $7.2 \%$ & $7.2 \%$ & $7.2 \%$ & $7.2 \%$ \\
\hline ING & Bank/Insurer & & & & & & & & & $7.4 \%$ & $7.4 \%$ & $7.4 \%$ & $7.4 \%$ & $7.4 \%$ & $7.4 \%$ & $7.4 \%$ \\
\hline Fortis & Bank/Insurer & & & & & & & & & $8.0 \%$ & $8.0 \%$ & $8.0 \%$ & $8.0 \%$ & $8.0 \%$ & $8.0 \%$ & $8.0 \%$ \\
\hline Aviva plc & Insurer & & & & & & & & & & & & & $5.1 \%$ & $5.1 \%$ & $5.0 \%$ \\
\hline Eureko & Insurer & & & & & & & & & & & & & & $4.9 \%$ & $4.9 \%$ \\
\hline
\end{tabular}

Note: Table shows the ownership structure of Ahold in May of each year. Before 1992 ownership stakes are taken from an annual stock market guide $D e$ Omzetcijfers published by Het Financieele Dagblad. After 1992 ownership stakes, other than the ownership of Argyll and Casino, are based on the notifications under the Act on Disclosure of Holdings in Listed Companies (Wet Melding Zeggenschap). Starting in 1997, the stakes are the combination of the ordinary shares and the certificates of preferred shares. 
Table 11: Ahold's management board

\begin{tabular}{|c|c|c|c|c|c|c|c|c|c|c|}
\hline Name & Nationality & Started & Ended & Expertise & 1987 & 1993 & 1998 & 2002 & 2003 & Employment/affiliations \\
\hline A. Heijn & Dutch & 1962 & 1989 & Retail & $\mathrm{C}$ & & & & & Heijn family \\
\hline C.H. van der Hoeven & Dutch & 1985 & 2003 & Finance & M & $\mathrm{C}$ & $\mathrm{C}$ & $\mathrm{C}$ & & $\begin{array}{l}\text { Former Royal Dutch/Shell; later in } \\
\text { supervisory board Stroeve bank, } \\
\text { ABN-Amro and KPN }\end{array}$ \\
\hline P.J. Everaert & U.S. & 1985 & 1993 & Marketing & M & & & & & Former Goodyear, General Biscuits \\
\hline P.J. van Dun & Dutch & 1980 & 1997 & Organization & M & M & & & & Former SHV \\
\hline F.I. Ahlqvist & Sweden & 1981 & 1998 & Marketing & M & M & M & & & Former Mölnlycke \\
\hline G.J. Heijn & Dutch & 1962 & 1988 & Retail & M & & & & & Heijn family \\
\hline R. Zwartendijk & Dutch & 1981 & 1999 & Production & $\mathrm{M}$ & M & $\mathrm{M}$ & & & Former Mölnlycke \\
\hline J.G. Andreae & Dutch & 1997 & 2004 & Retail & & & M & M & & $\begin{array}{l}\text { Former Albert Heijn and since } \\
1979 \text { Ahold }\end{array}$ \\
\hline A.M. Meurs & Dutch & 1997 & 2003 & Finance & & & M & M & & $\begin{array}{l}\text { Former ABN-Amro; since } 1992 \\
\text { Ahold; also supervisory board Van } \\
\text { der Hoop bank }\end{array}$ \\
\hline E.S. Moerk & Norway & 1994 & 1998 & $\begin{array}{l}\text { International } \\
\text { business }\end{array}$ & & & M & & & $\begin{array}{l}\text { Former Canada Dry, Pepsi and } \\
\text { Campbells’ Biscuits }\end{array}$ \\
\hline M.P.M. de Raad & Dutch & 2001 & Present & Retail & & & & M & M & $\begin{array}{l}\text { Former SHV, Metro AG, CSM and } \\
\text { Hagemeyer }\end{array}$ \\
\hline W.J. Grize & U.S. & 2001 & Present & Retail & & & & M & M & Management Stop \& Shop \\
\hline J.L. Miller & U.S. & 2001 & Present & Retail & & & & $\mathrm{M}$ & $\mathrm{M}$ & Management US Food Service \\
\hline A.S. Noddle & U.S. & 1998 & 2001 & Retail & & & & & & Management Giant Food Stores \\
\hline P. Wakkie & Dutch & 2003 & Present & Legal & & & & & $\mathrm{M}$ & $\begin{array}{l}\text { Former De Brauw Blackstone } \\
\text { Westbroek }\end{array}$ \\
\hline A. Moberg & Sweden & 2003 & Present & Marketing & & & & & $\mathrm{C}$ & Former Ikea \\
\hline H. Ryopponen & Sweden & 2003 & Present & Finance & & & & & M & Former Ikea \\
\hline D. Eustace & U.K. & 2003 & Present & Finance & & & & & $\mathrm{M}$ & Former CFO Philips \\
\hline
\end{tabular}

Note: Table shows the development of the management board of Ahold from 1987 to 2004. C denotes CEO and M denotes management board member. Data is collected from annual reports and REACH database. 
Table 12: Ahold's supervisory board

\begin{tabular}{|c|c|c|c|c|c|c|c|c|c|c|}
\hline Name & Nationality & Started & Ended & Expertise & 1987 & 1993 & 1998 & 2002 & 2003 & Employment/affiliations \\
\hline J. Kreiken & Dutch & 1969 & 1990 & Business & $\mathrm{C}$ & & & & & $\begin{array}{l}\text { Nationale Investeringsbank, chair } \\
\text { until May } 1987\end{array}$ \\
\hline D. Vethaak & Dutch & 1981 & 1987 & Finance & M & & & & & $\begin{array}{l}\text { Was in management board from } \\
1959-1981\end{array}$ \\
\hline A. Spaander & Dutch & 1981 & 1993 & Unknown & $\mathrm{M}$ & M & & & & \\
\hline A.J. Kranendonk & Dutch & 1985 & 2000 & $\begin{array}{l}\text { Business, } \\
\text { Finance }\end{array}$ & M & & & & & $\begin{array}{l}\text { Former diary cooperation } \\
\text { Friesland, also on supervisory } \\
\text { board of Athlon, also DNB }\end{array}$ \\
\hline J.H. Choufoer & Dutch & 1985 & 1996 & Business & M & $\mathrm{C}$ & & & & $\begin{array}{l}\text { Former RD/Shell, also on } \\
\text { supervisory board of RD/Shell, } \\
\text { ING, Hoogovens and Pakhoed }\end{array}$ \\
\hline G. van 't Hull & Dutch & 1972 & 1988 & Unknown & $\mathrm{M}$ & & & & & \\
\hline J.F.A. de Soet & Dutch & NA & 1988 & Marketing & M & M & & & & $\begin{array}{l}\text { Former KLM, also } 18 \text { other } \\
\text { supervisory directorships }\end{array}$ \\
\hline R.J. Nelissen & Dutch & 1981 & 2001 & $\begin{array}{l}\text { Finance, } \\
\text { Politics }\end{array}$ & M & M & M & & & $\begin{array}{l}\text { Former ABN-Amro, DNB, } \\
\text { parliament and minister, also } 18 \\
\text { supervisory directorships including } \\
\text { Deloitte, GTI and ABN-Amro }\end{array}$ \\
\hline $\begin{array}{l}\text { N. Rempt- } \\
\text { Halmmans de Jongh }\end{array}$ & Dutch & 1979 & 1992 & Politics & $\mathrm{M}$ & & & & & Member of parliament \\
\hline R.J. Bogomolny & U.S. & 1992 & 1998 & Retail & & M & M & & & $\begin{array}{l}\text { Former CEO of First National } \\
\text { Supermarkets }\end{array}$ \\
\hline A. Heijn & Dutch & 1990 & 1997 & N.a. & & M & & & & $\begin{array}{l}\text { Family; was in management board } \\
\text { 1962-1989; also supervisory } \\
\text { director at Athlon, Randstad, } \\
\text { Reesink, ABN-Amro }\end{array}$ \\
\hline J. de Koning & Dutch & 1991 & 1994 & Politics & & M & & & & $\begin{array}{l}\text { Member of parliament and minister } \\
\text { (died in 1994) }\end{array}$ \\
\hline R.F. Meyer & U.S. & 1988 & 2000 & Academic & & M & M & & & $\begin{array}{l}\text { Finance professor at Harvard } \\
\text { Business School }\end{array}$ \\
\hline
\end{tabular}


Table 12: Ahold's supervisory board (continued)

\begin{tabular}{|c|c|c|c|c|c|c|c|c|c|c|}
\hline Name & Nationality & Started & Ended & Expertise & 1987 & 1993 & 1998 & 2002 & 2003 & Employment/affiliations \\
\hline H. de Ruiter & Dutch & 1994 & 2003 & Business & & & $\mathrm{C}$ & $\mathrm{C}$ & & $\begin{array}{l}\text { Former RD/Shell, also } 17 \\
\text { supervisory directorships including } \\
\text { RD/Shell, Heineken, } \\
\text { Hoogovens/Corus, Pakhoed }\end{array}$ \\
\hline J.A. van Kemenade & Dutch & 1996 & 2001 & $\begin{array}{l}\text { Politics, } \\
\text { Academic }\end{array}$ & & & M & & & $\begin{array}{l}\text { Former parliament and minister, } \\
\text { mayor, chaired university, DNB }\end{array}$ \\
\hline M. Perry CBE & U.K. & 1997 & Present & Business & & & M & M & M & Former Unilever \\
\hline L.J.R. de Vink & Dutch & 1998 & Present & $\begin{array}{l}\text { International } \\
\text { business }\end{array}$ & & & & $\mathrm{M}$ & M & Former Warner Lambert \\
\hline R. Fahlin & Sweden & 2001 & 2003 & Retail & & & & $\mathrm{M}$ & & Management ICA \\
\hline C.P. Schneider & U.S. & 2001 & Present & Academic & & & & M & M & $\begin{array}{l}\text { Art professor, former US } \\
\text { ambassador in the Netherlands }\end{array}$ \\
\hline R.G. Tobin & U.S. & 2001 & Present & $\begin{array}{l}\text { Retail, } \\
\text { Marketing }\end{array}$ & & & & M & M & $\begin{array}{l}\text { Management Stop \& Shop, was in } \\
\text { management board 1998-2001 }\end{array}$ \\
\hline C. Boonstra & Dutch & 2001 & 2002 & Marketing & & & & & & Former Philips \\
\hline J. Hommen & Dutch & 2003 & Present & Finance & & & & & M & Former Philips \\
\hline K. Vuursteen & Dutch & 2002 & Present & Business & & & & & $\mathrm{C}$ & Former Philips and Heineken \\
\hline
\end{tabular}

Note: Table shows the development of the supervisory board of Ahold from 1987 to 2004. C denotes Chairman and M denotes supervisory board member. Data

is collected from annual reports, REACH database, and www.parlement.com. 
Table 13: Ahold's board compensation and stock options

\begin{tabular}{|c|c|c|c|c|c|c|c|c|c|c|c|c|}
\hline \multirow[t]{2}{*}{$\begin{array}{l}\text { Year } \\
\end{array}$} & \multirow{2}{*}{$\begin{array}{l}\text { Management } \\
\text { board compen- } \\
\text { sation (in } \\
\text { thousands } € \text { ) }\end{array}$} & \multirow{2}{*}{$\begin{array}{l}\text { Supervisory } \\
\text { board } \\
\text { compen- } \\
\text { sation (in } \\
\text { thousands } € \text { ) }\end{array}$} & \multicolumn{7}{|c|}{ Stock option plans } & \multirow[b]{2}{*}{$\begin{array}{l}\text { Average } \\
\text { monthly } \\
\text { stock price } \\
\text { during the } \\
\text { calendar } \\
\text { year (in } € \text { ) }\end{array}$} & \multirow[b]{2}{*}{ 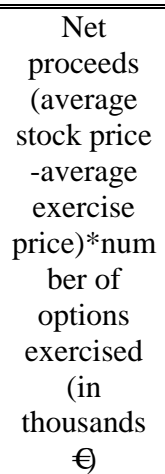 } & \multirow[b]{2}{*}{$\begin{array}{c}\text { Ratio (net } \\
\text { proceeds/m } \\
\text { anagement } \\
\text { board } \\
\text { compensati } \\
\text { on) }\end{array}$} \\
\hline & & & $\begin{array}{l}\text { Number of } \\
\text { options } \\
\text { beginning of } \\
\text { year for board } \\
\text { and top } \\
\text { management }\end{array}$ & $\begin{array}{l}\text { Number of } \\
\text { options for } \\
\text { board } \\
\text { members }\end{array}$ & $\begin{array}{l}\text { Number of } \\
\text { options } \\
\text { granted }\end{array}$ & $\begin{array}{l}\text { Number of } \\
\text { options } \\
\text { exercised }\end{array}$ & $\begin{array}{l}\text { Number of } \\
\text { options } \\
\text { cancelled }\end{array}$ & $\begin{array}{l}\text { Average } \\
\text { price of } \\
\text { options } \\
\text { exercised } \\
\text { (in €) }\end{array}$ & $\begin{array}{l}\text { Price range } \\
\text { options } \\
\text { outstanding year } \\
\text { end / average } \\
\text { price options } \\
\text { outstanding } \\
\text { (in } € \text { ) }\end{array}$ & & & \\
\hline $1987^{-}$ & $2,643.3$ & 316.3 & 0 & NA & $1,013,100$ & - & - & - & 3.95 & 3.44 & 0 & 0 \\
\hline 1988 & $2,501.2$ & 417.9 & $1,013,100$ & NA & $1,726,200$ & 327,600 & - & 2.23 & $2.23-3.95$ & 3.00 & 252.2 & 0.1 \\
\hline 1989 & $2,560.7$ & 270.0 & $2,411,700$ & NA & $2,021,400$ & $2,145,600$ & - & 3.36 & $2.23-3.95$ & 5.13 & $3,797.7$ & 1.5 \\
\hline 1990 & $3,178.3$ & 280.9 & NA & NA & NA & NA & - & NA & NA & 4.94 & NA & NA \\
\hline 1991 & 3,192.3 & 324.0 & $6,351,588$ & NA & $3,241,602$ & $1,825,386$ & - & 4.06 & $2.17-5.05$ & 5.99 & $3,523.0$ & 1.1 \\
\hline 1992 & $4,014.6$ & 326.3 & $7,767,804$ & NA & $2,877,516$ & $1,717,440$ & - & 4.19 & $3.28-6.42$ & 6.22 & $3,486.4$ & 0.9 \\
\hline 1993 & 3,933.4 & 289.1 & $8,927,880$ & NA & $3,480,984$ & $2,149,155$ & 124,161 & 4.87 & $4.88-7.35$ & 7.02 & $4,620.7$ & 1.2 \\
\hline 1994 & 3,923.4 & 255.0 & $10,259,709$ & NA & $3,794,106$ & $1,246,140$ & 22,656 & 5.27 & $8.12-4.85$ & 7.43 & $2,691.7$ & 0.7 \\
\hline 1995 & $4,050.0$ & 248.2 & $12,785,019$ & NA & $3,928,416$ & $2,318,010$ & 136,329 & 5.79 & $9.91-4.82$ & 8.63 & 6,583.1 & 1.6 \\
\hline 1996 & $4,789.2$ & 241.0 & $14,289,096$ & NA & $4,324,677$ & $3,847,743$ & 292,527 & 5.30 & $5.81-16.33$ & 13.54 & $31,705.4$ & 6.6 \\
\hline 1997 & $6,814.4$ & 248.2 & $14,473,503$ & NA & $4,860,657$ & $3,133,703$ & 205,863 & 5.82 & $14.43^{\#}$ & 22.31 & $51,674.8$ & 7.5 \\
\hline 1998 & $6,013.5$ & 222.4 & $15,994,594$ & NA & $5,768,455$ & $3,794,299$ & 190,487 & 9.60 & 20.50 & 28.47 & $71,589.4$ & 11.9 \\
\hline 1999 & $6,304.0$ & 238.0 & $17,778,263$ & $2,047,880$ & $5,744,762$ & $1,912,239$ & 146,172 & 10.90 & 23.36 & 32.87 & $41,011.9$ & 6.7 \\
\hline 2000 & $10,210.0$ & 272.0 & $21,464,560$ & $2,345,702$ & $8,662,015$ & $3,097,069$ & 824,558 & 13.48 & 27.81 & 30.11 & $51,504.3$ & 5.1 \\
\hline 2001 & $18,658.0$ & 257.0 & $26,204,948$ & $3,049,909$ & $9,111,459$ & $3,159,639$ & 495,366 & 17.87 & 30.03 & 33.82 & $50,396.6$ & 2.7 \\
\hline 2002 & $20,345.0$ & 278.0 & $22,741,899$ & $2,027,059$ & $8,291,770$ & 392,525 & $4,083,058$ & 16.01 & 29.00 & 20.27 & $1,672.2$ & 0.1 \\
\hline 2003 & $10,532.0$ & $1,662.0$ & $27,185,819$ & 758,096 & $8,978,750$ & 92,371 & $3,498,468$ & 10.07 & 25.19 & 6.60 & 0 & 0 \\
\hline
\end{tabular}

Note: Table shows information on board compensation (salary, bonus and pensions) and stock option plans from 1993 to 2003. Data is collected from Dutch annual reports during 1987-1990. The annual report of 1990 does not contain information about the stock option plan. As from 1991 onwards the data comes from form 20-F filings with the SEC. About 150 employees qualify for stock options in the period 1987-1997. 820 employees have been granted stock options in 1998-1999. In 2000 there are 5,000 employees that have been granted stock options. This increases to 6,700 employees in 2001. Number of options has been adjusted for 1 for 2 stock split in 1993 and 1990 and a 3 for 1 stock split in 1997. "From 1997, the annual reports disclose the average price of the options outstanding instead of a price range of options outstanding. The last three columns report the average monthly stock price during the calendar year, the net proceeds from the options exercised, and the ratio of the net proceeds to the management board's other compensation (salary, bonus and pensions). Stock price data is from Datastream and adjusted for stock splits. NA denotes not available. 
Figure 1: Ahold's stock price performance

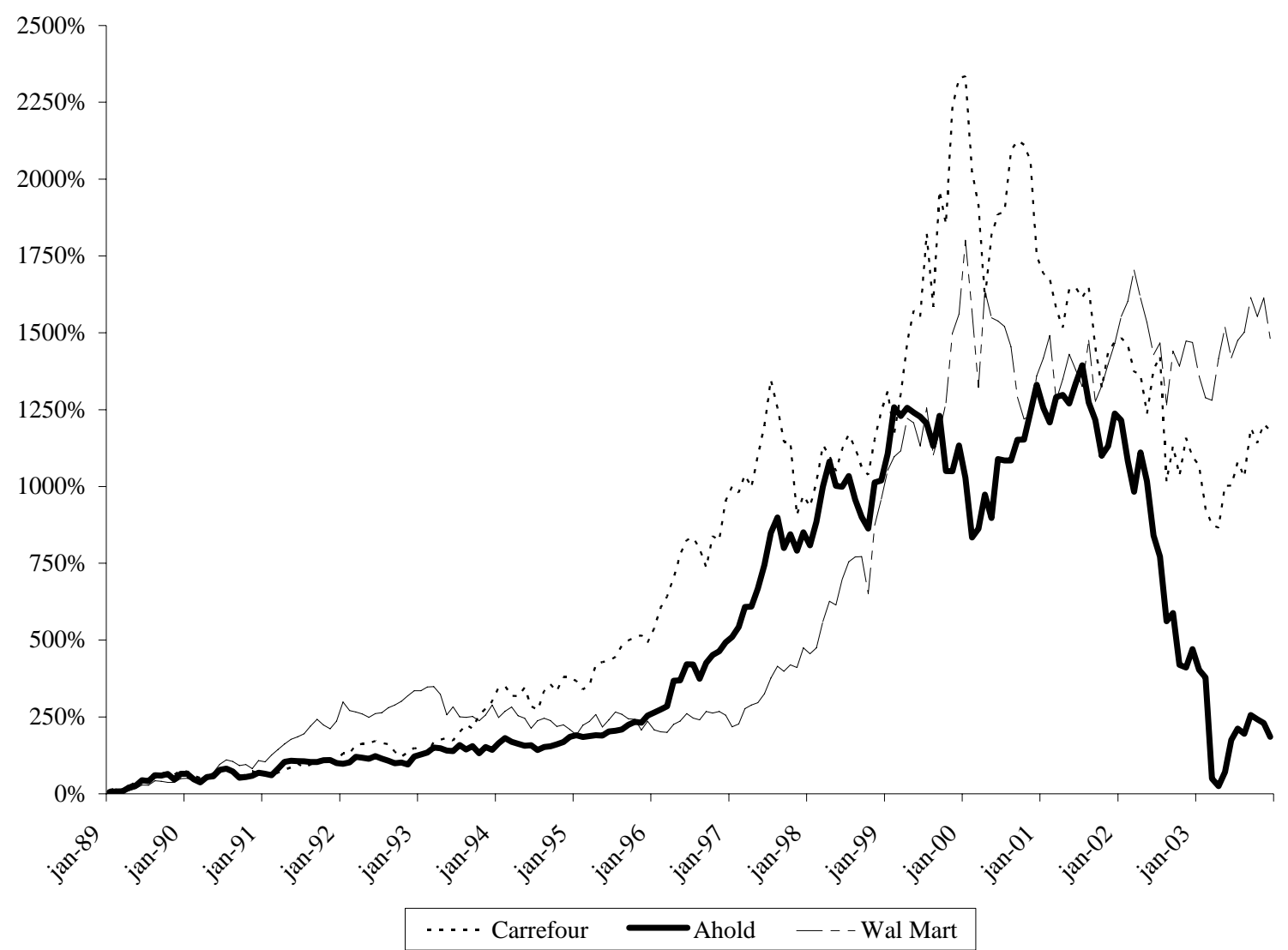

Note: Figure shows the buy-and-hold returns of Ahold, Carrefour, and Wal-Mart from January 1989 to December 2003. Data is collected from Datastream. 
Figure 2: Number of acquisitions

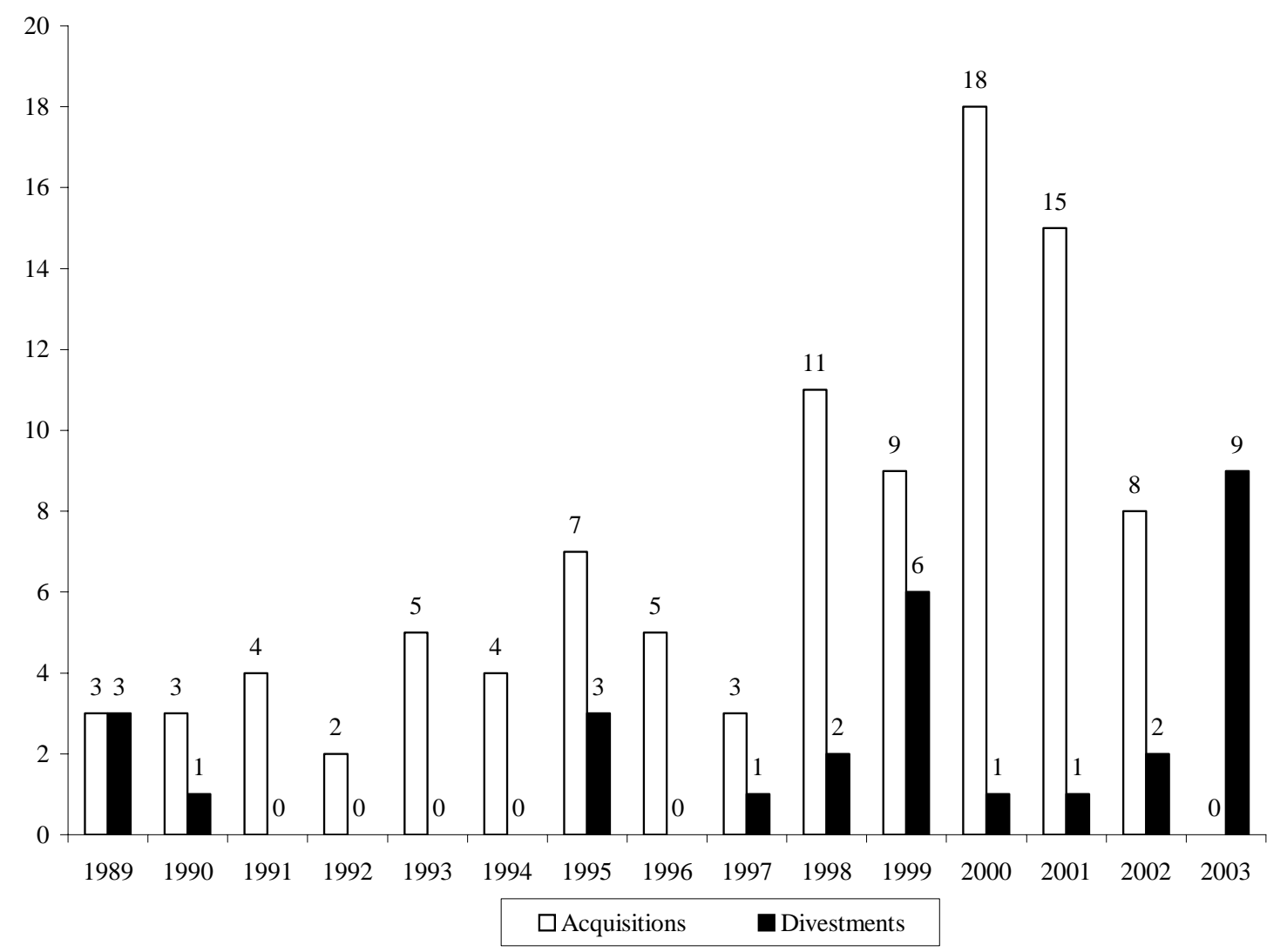

Note: Figure shows the number of acquisitions and divestments of Ahold during 1989-2003. Data is collected from annual reports, newspapers and the ZEPHYR, SDC Mergers \& Acquisitions databases. 
Figure 3: Capital raising by Ahold 1989-2003

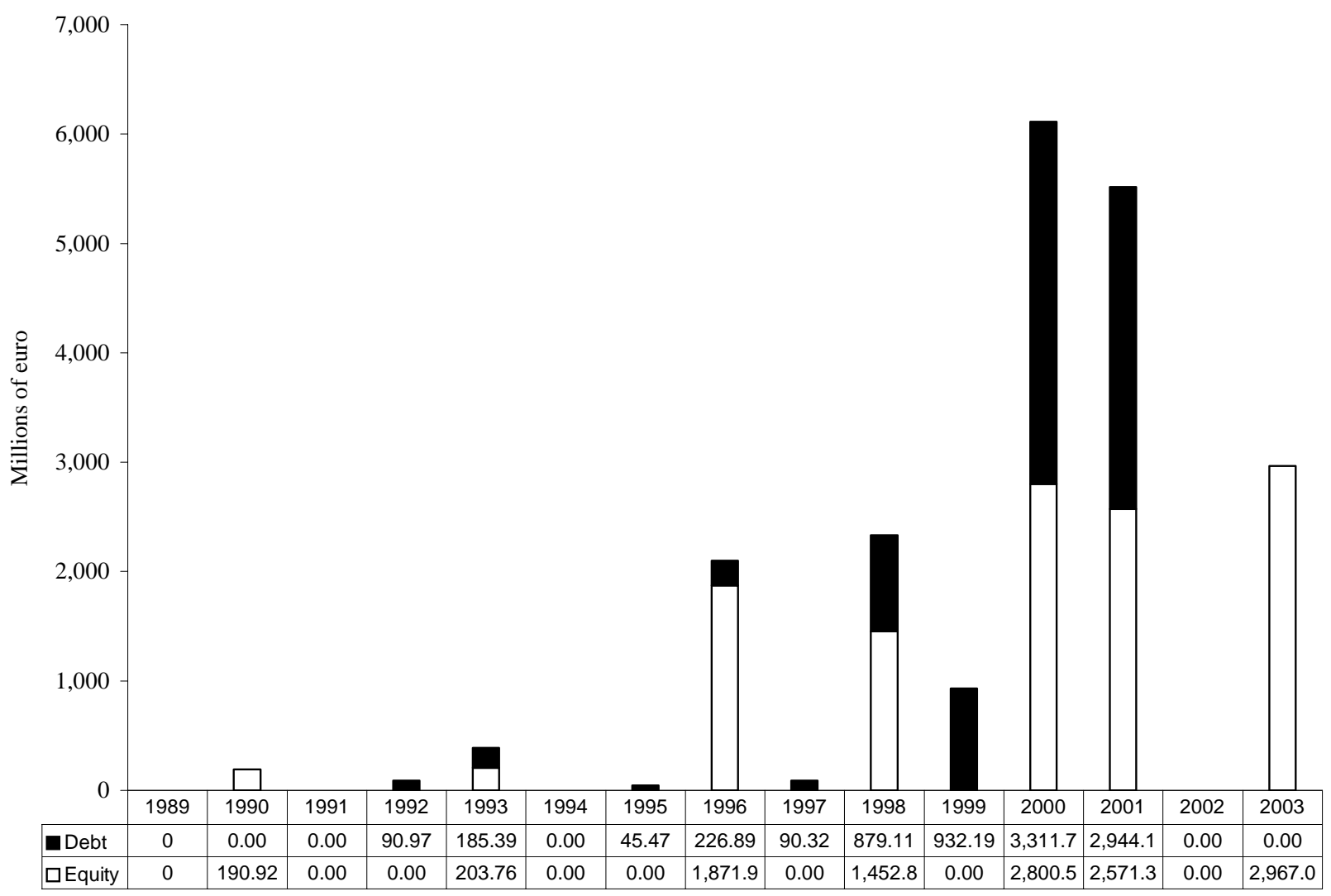

Note: Figure shows the proceeds of equity and debt offerings of Ahold during 1989-2003 in € million. Debt and equity offerings are identified through the SDC New Issues database and a Lexis Nexis search. 
Figure 4: Analyst recommendations of Ahold

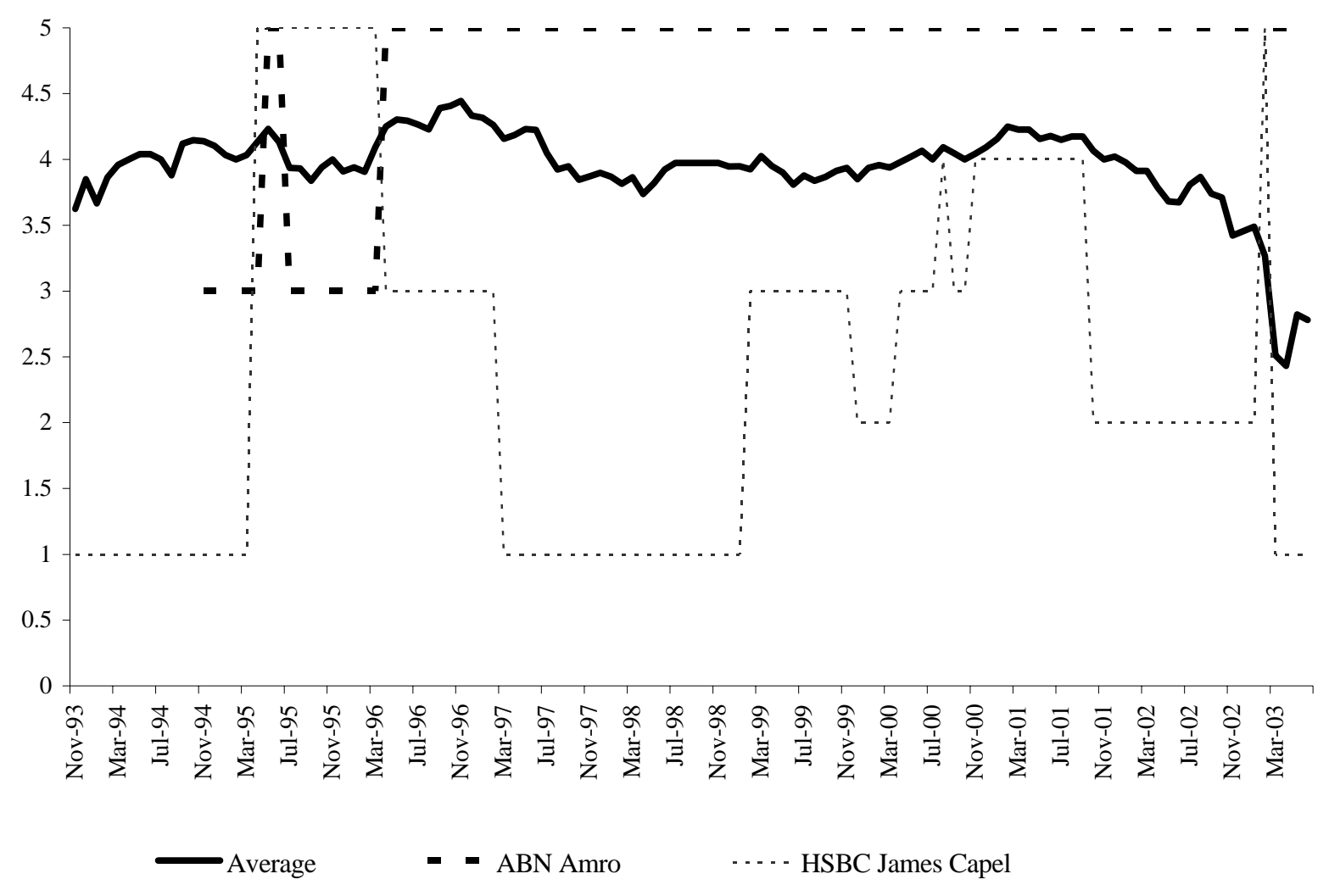

Note: Figure shows the average analyst recommendation per month (5=strong buy, 4=buy, 3=hold, 2=sell and 1=strong sell). The graph shows that the average analyst opinion was positive until 2003 (with the average score above 3). In total there were 490 analyst recommendations covered in the IBES/First Call database. The coverage begins in November 1993 and our data ends in June 2003. For ABN-Amro (the bank with the most optimistic forecasts in the IBES/First Call database) coverage starts in November 1994 and ends in May 2003. For HSBC James Capel (the bank with the most pessimistic forecasts in the IBES/First Call database) coverage starts in November 1993 and ends in June 2003. 


\section{Publications in the Report Series Research* in Management}

ERIM Research Program: "Finance and Accounting"

2005

Royal Ahold: A Failure Of Corporate Governance

Abe De Jong, Douglas V. Dejong, Gerard Mertens en Peter Roosenboom

ERS-2005-002-F\&A

\footnotetext{
* A complete overview of the ERIM Report Series Research in Management: https://ep.eur.nl/handle/1765/1

ERIM Research Programs:

LIS Business Processes, Logistics and Information Systems

ORG Organizing for Performance

MKT Marketing

F\&A Finance and Accounting

STR Strategy and Entrepreneurship
} 